$1-2008$

\title{
Biochemical Applications of Ultrathin Films of Enzymes, Polyions and DNA
}

James F. Rusling

University of Connecticut School of Medicine and Dentistry

Dominic O. Hull

University of Connecticut - Storrs

Eli G. Hvastkovs

University of Connecticut - Storrs

John B. Schenkman

University of Connecticut School of Medicine and Dentistry

Follow this and additional works at: https://opencommons.uconn.edu/uchcres_articles Part of the Life Sciences Commons, and the Medicine and Health Sciences Commons

\section{Recommended Citation}

Rusling, James F.; Hull, Dominic O.; Hvastkovs, Eli G.; and Schenkman, John B., "Biochemical Applications of Ultrathin Films of Enzymes, Polyions and DNA" (2008). UCHC Articles - Research. 170.

https://opencommons.uconn.edu/uchcres_articles/170 


\title{
Biochemical applications of ultrathin films of enzymes, polyions and DNA
}

\author{
James F. Rusling ${ }^{*}, a, b$, Eli G. Hvastkovs ${ }^{a}$, Dominic O. Hulla, and John B. Schenkman ${ }^{b}$ \\ aDepartment of Chemistry, 55 N. Eagleville Rd., University of Connecticut, Storrs, CT, 06269, \\ USA \\ bDepartment of Pharmacology, University of Connecticut Health Center, Farmington, CT, 06032, \\ USA
}

\begin{abstract}
This feature article summarizes recent applications of ultrathin films of enzymes and DNA assembled layer-by-layer (LbL). Using examples mainly from our own research, we focus on systems developed for biocatalysis and biosensors for toxicity screening. Enzyme-poly(L-lysine) (PLL) films, especially when stabilized by crosslinking, can be used for biocatalysis at unprecedented high temperatures or in acidic or basic solutions on electrodes or sub-micron sized beads. Such films have bright prospects for chiral synthesis and biofuel cells. Excellent bioactivity and retention of enzyme structure in these films facilitates their use in detailed kinetic studies. Biosensors and arrays employing DNA-enzyme films show great promise in predicting genotoxicity of new drug and chemical product candidates. These devices combine metabolic biocatalysis, reactive metabolite-DNA reactions, and DNA damage detection. Catalytic voltammetry or electrochemiluminescence (ECL) can be used for high throughput arrays utilizing multiple LbL "spots" of DNA, enzyme and metallopolymer. DNA-enzyme films can also be used to produce nucleobase adduct toxicity biomarkers for detection by LC-MS. These approaches provide valuable high throughput tools for drug and chemical product development and toxicity prediction.
\end{abstract}

\section{Introduction}

In the early 1990s, Decher, Lvov and co-workers ${ }^{1-3}$ developed a versatile, revolutionary, yet simple method to prepare multicomponent films of polyions and other charged materials. Biomolecular polyions such as DNA, RNA and proteins as well as inorganic nanoparticles can be included in these films. ${ }^{4-6}$ Construction begins by adsorbing an initial layer of charged polyion from solution onto an oppositely charged solid surface. Loosely bound polyions are removed by washing with water, then a second layer of polyions of the opposite charge to the first is adsorbed. For example, if the first layer is a polycation, the second should be a polyanion. This sequence of layer adsorption is repeated, changing the sign of the polyion, and consequently the surface charge, at every other adsorption step.

Different components can be used in different adsorption steps, as long as polyions in alternate steps have opposite charges. In this way layered films containing two or more different enzymes, ${ }^{7}$ proteins and nanoparticles, ${ }^{5}$ or DNA and enzymes ${ }^{8}$ can be built up. Moderate concentrations of the polyions in the adsorbate solutions, typically 0.5 to $3 \mathrm{mg}$ $\mathrm{mL}^{-1}$, provide excess adsorption at each step. That is, adsorption of the new polyion onto 
the oppositely charged polyion layer leads to internal charge neutralization, but reverses the original charge on the surface. ${ }^{4,5}$ This procedure results in very stable films because as each layer is added weakly adsorbed polyions are washed off, thus selecting only the strongest interactions between each neighboring layer. Some polyions that have been used to make these films are shown below. They include metal oxide nanoparticles and DNA. It is important to realize that even though the films are constructed one layer at a time, there is extensive intermixing between three or more neighboring layers within the film, and the internal structure is somewhat disordered. , $, 5,7,9^{-1}$

This layer-by-layer (LbL) film assembly method has become widely popular. It has been employed for numerous applications in many fields, as discussed in a recent review. ${ }^{10} \mathrm{~A}$ number of interactions other than electrostatic can be utilized for film construction. ${ }^{11}$ Herein we present a short account of our biochemically-related applications utilizing LbL films, first to make stable films of enzymes and polyions for biocatalysis, and second to make films of DNA, metabolic enzymes and polyions for toxicity screening.

In the mid 1990s, Yuri Lvov joined our group at the University of Connecticut as a senior research scientist after having spent five years working in Japan. By this time, with Ariga and Kunitake, he had already demonstrated biocatalytic films prepared by the LbL method. ${ }^{12}$ Lvov and I specifically wished to apply the LbL method to facilitate direct electrochemical activation of metabolic enzymes on solid electrodes. Our goal, somewhat vague at that time, was to make future devices useful for drug development and toxicity screening.

Some ionic polymers used for film formation

Polycations
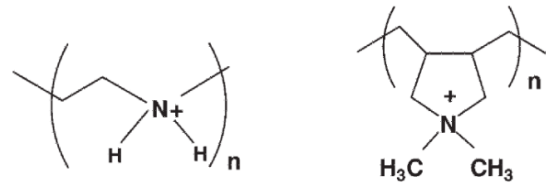

poly(ethylene imine) (PEI)

poly(diallydimethylamine) (PDDA)

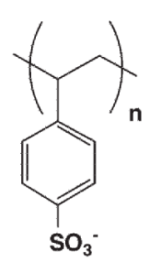

Polyanions

poly(styrenesulfonate) (PSS)

$$
\begin{gathered}
{[\text { DNA }]} \\
\text { nanoparticles: } \\
\mathrm{TiO}_{2} \quad \mathrm{MnO}_{2} \\
\mathrm{SiO}_{2} \quad \text { Clay }
\end{gathered}
$$

\section{Film construction and enzyme voltammetry}

Up until about 20 years ago, direct voltammetry of redox proteins was a difficult proposition, and was seriously plagued by fouling of electrodes by the proteins, which often denatured on the electrode surface. ${ }^{13}$ In the late 1980 s and early 1990 s, direct, reversible voltammetry of cyt $\mathrm{c}$ in phosphatidylcholine films was reported. ${ }^{14-16}$ Also, Armstrong et al. co-adsorbed proteins with aminocyclitols and polymixins on edge plane pyrolytic graphite electrodes to give reversible voltammetry. ${ }^{17}$ Tarlov and Bowden showed that self-assembled monolayers (SAMs) of alkylthiolcarboxylates on gold adsorb positively charged cyt c to 
give reversible voltammetry. ${ }^{18}$ These seminal reports demonstrated approaches to and the value of protein film voltammetry, which provides direct electron transfer between redox proteins or enzymes and electrodes in many cases. A key is to place the protein in a film or on a surface that protects it from denaturing and fouling the electrode.

One focus of our protein film voltammetry has been the cytochrome (cyt) P450s, which are the major Phase I metabolic enzymes catalyzing substrate oxidations in the human liver. ${ }^{19,20}$ While these enzymes evolved to produce metabolites that are easily excreted from the body, in some cases lipophilic chemicals or drugs are bioactivated to reactive metabolites. Bioactivation produces metabolites that can form covalent adducts with DNA bases, proteins, and other biomolecules, and is a major source of toxicity. ${ }^{21-24}$

Cyt $\mathrm{P} 450$ s are iron-heme proteins $(\mathrm{P}-\mathrm{Fe})$ that catalyze the transfer of oxygen atoms to organic substrates. ${ }^{19,20,25}$ Scheme 1 depicts the currently accepted mechanistic model for cyt P450 catalysis. Initially, the resting state of the catalytic iron heme site contains a water molecule bound to the distal side of $\mathrm{P}-\mathrm{Fe}(\mathrm{III})$ (1). This water freely exchanges with its environment and does not participate in oxygen transfer reactions. ${ }^{25}$ This form of the enzyme binds substrate RH and eliminates the distal water (2). Substrate is not bound directly to the heme iron of $\mathrm{P}-\mathrm{Fe}(\mathrm{mI})$, but sits above it in a hydrophobic pocket within the protein. Next, 2 is reduced by one electron to the P-Fe(II) state by a NADPH-dependent reductase to give 3. $\mathrm{P}-\mathrm{Fe}$ (II) 3 then binds dioxygen at the distal site to form a ferrousdioxygen or ferric superoxy complex (4). ${ }^{20,26-28}$ This complex is converted via a one electron reduction to give $\mathbf{5}$, which is then protonated to give $\mathbf{6}$. The electron to generate complex $\mathbf{5}$ is donated from NADPH-dependent reductase in most cases. The P-Fe(III)-OOH (6) can also be generated by addition of hydrogen peroxide or organic peroxides in a reversible process termed the peroxide shunt. Once $\mathbf{6}$ is formed, protonation and $\mathrm{O}-\mathrm{O}$ bond cleavage leads to elimination of water and formation of the highly reactive heme-iron(rv)oxo radical cation $\left\{\left(\mathrm{P}^{\bullet+}\right) \mathrm{Fe}(\mathrm{Iv})-\mathrm{oxo}, 7\right\}$, which transfers oxygen to bound substrate to generate product $(\mathrm{ROH})$. The product dissociates from the enzyme and the distal site is reoccupied by an exchangeable water and is ready for another substrate turnover. Species 6 can regenerate peroxide, and $\mathbf{7}$ can reverse through a two-electron, two-proton process to form the substrate bound $\mathbf{2}$. In addition, exposure of the ferrous form of the protein $\mathbf{3}$ to carbon monoxide gas produces the $\mathrm{P}-\mathrm{Fe}(\mathrm{II})-\mathrm{CO}$ complex 9 that absorbs light at $\sim 450 \mathrm{~nm}$, which gives these enzymes their characteristic name.

When we began our studies of cyt P450s, we felt that direct voltammetry in films on electrodes might provide an easy route to enzyme catalyzed metabolite formation. This could then serve as the basis of high throughput tools for investigations of metabolism, drug development, enzyme inhibition, and toxicity. After we published the first report on enzyme film voltammetry and catalysis with bacterial cyt $\mathrm{P} 450$ cam using lipid films,${ }^{29}$ we suspected that LbL films might provide more stability and better versatility for our applications.

In 1998, Lvov's work in our lab led to the first report of direct enzyme voltammetry in LbL films on electrodes. ${ }^{30}$ Reversible voltammetry was obtained for films of iron heme proteins myoglobin $(\mathrm{Mb})$ and bacterial cyt $\mathrm{P} 450_{\text {cam }}$, which are models for human metabolic cyt P450s. An initial negative charge on a gold electrode was obtained by treatment with mercaptopropane sulfonic acid. This or some other initial negative monolayer on gold was essential to obtain reversible protein voltammetry; without it, no protein CVs were obtained. The negatively-charged electrode was then immersed into a $1-3 \mathrm{mg} \mathrm{mL}^{-1}$ solution of polycations, washed, then immersed in a solution of polyanion (Fig. 1). The polyions adsorbed at steady state coverage in about 15-20 min, effectively reversing the charge on the solid surface at each step. After rinsing in water, this electrode was immersed in a 1-3 $\mathrm{mg} \mathrm{mL}^{-1}$ solution of positively charged proteins. The positive surface charge on the protein 
is achieved by dissolving it in buffer of $\mathrm{pH}$ below its isoelectric point. After protein is adsorbed, the surface develops a positive charge. Adsorption of polyanion and protein are repeated to obtain the desired number of reproducible alternating layers. Film growth was monitored during and after each adsorption step with quartz crystal microbalance (QCM) weighing (Fig. 2(a), (b)), spectroscopy and voltammetry.

The frequency of a QCM resonator decreases in proportion to the mass on its metal coating. ${ }^{31}$ Drying before measurement minimizes bias from interfacial viscoelasticity changes. In-situ QCM on MPS-coated gold/quartz resonators showed that adsorption saturation for protein and polyion layers occurs in 15-20 min (Fig. 2(a)). For $9 \mathrm{MHz}$ quartz resonators, mass per unit area $M / A\left(\mathrm{~g} \mathrm{~cm}^{-2}\right)$ of the film layer is related to the QCM frequency shift $\Delta F(\mathrm{~Hz})$ by ${ }^{4}$

$$
M / A=-\Delta F /\left(1.83 \times 10^{8}\right)
$$

where $A$ is the area of the gold disk on the quartz resonator in $\mathrm{cm}^{2}$. The empirical relation between $\Delta F$ and nominal film thickness ( $d$ ) for proteins and polyions is: ${ }^{12}$

$$
d(\mathrm{~nm}) \approx-(0.016 \pm 0.002) \Delta F(\mathrm{~Hz})
$$

QCM frequency changes after each layer of the film is adsorbed are illustrated for an LbL assembly of Mb and DNA on an MPS-Au surface (Fig. 2(b)). Frequency of the dried film decreased linearly and reproducibly for the adsorption steps as expected for reproducible layer formation. From eqn (2), the total thickness of this film of 18 layers is $\sim 95 \mathrm{~nm}$. The fraction of electroactive protein is obtained by dividing the electroactive mass of protein obtained from integrating voltammograms by the total protein mass measured by QCM. Enzymes were catalytically active in the DNA films, a property we utilized later for toxicity screening. Visible absorbance spectra of the Mb/DNA films gave the characteristic Soret band for intact $\mathrm{Mb}$ at $411 \mathrm{~nm}$ (Fig. 2(c)).

LbL films of $\mathrm{Mb}$ and cyt $\mathrm{P} 450_{\text {cam }}$ gave chemically reversible cyclic voltammograms for the

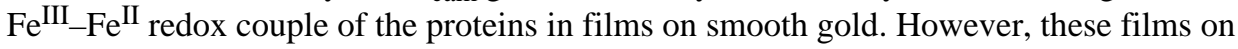
gold had only $\sim 1.3$ electroactive layers of protein. The number of electroactive layers was increased by growing films on roughened pyrolytic graphite (PG) electrodes, which may provide a disorder-inducing template that decreases average interprotein distance in the film and enables more efficient "electron hopping" between redox sites. In addition, coiled polyions adsorbed from solutions with relatively high salt concentrations provide much more adsorbed protein in the subsequent adsorption step compared to thinner polyion layers adsorbed from water. Films made on rough PG electrodes by adsorbing PSS from $0.5 \mathrm{M}$ $\mathrm{NaCl}$ and $\mathrm{Mb}$ from dilute $\mathrm{pH} 5.5$ buffer gave up to $7 \mathrm{Mb}$ electroactive layers. ${ }^{32}$ Similar results were found for cyt P450 films as illustrated by Fig. 3. ${ }^{33}$

A detailed study of polyion-cyt P450 binding and orientation during LbL film growth was done using QCM and AFM. ${ }^{34}$ As first layers on silver-coated QCM resonators, both cationic PEI and anionic PSS formed polymer islands featuring globular structures of $\sim 10 \mathrm{~nm}$ in diameter as visualized by AFM. By the time the fifth layer of protein or polyion was deposited, the film surface was relatively smooth. Cyt P450s have non-uniform charge distributions with negative and positive sides, and could be oriented with either end up by controlling the charge of the polyion layer onto which the protein was adsorbed. 


\section{Biocatalysis}

\section{Oxidations with LbL enzyme films}

Scheme 2 illustrates the general chemical-electrochemical pathway for cyt P450 and peroxidase catalyzed oxidations of organic reactant $(R)$ involving oxygenation ${ }^{30,33,35}$ and carbon-carbon bond formation. ${ }^{36,37}$ Compound I represents the ${ }^{\circ} \mathrm{PFe}^{\mathrm{IV}}=\mathrm{O}$ radical form of the enzyme obtained by reaction with peroxides that can transfer oxygen to or accept electrons from substrate R. For peroxidases, compound II, the non-radical $\mathrm{PFe}^{\mathrm{IV}}=\mathrm{O}$, can also oxidize substrates. Scheme 1 can be driven by electrochemical catalytic reduction of oxygen to $\mathrm{H}_{2} \mathrm{O}_{2}$ (on right) or by adding $\mathrm{H}_{2} \mathrm{O}_{2}$ (on left).

$\mathrm{Mb}$ serves as a good model and control for cyt P450 enzymology, since it is an iron heme protein that catalyzes some of the same reactions, but less efficiently. For LbL films of $\mathrm{Mb}$ or cyt $\mathrm{P} 450_{\text {cam }}$, with oxygen in solution, two electrons are transferred to the $\mathrm{PFe}^{\mathrm{II}}-\mathrm{O}_{2}$ complexes, as in the upper right hand corner of Scheme 2 to yield $\mathrm{H}_{2} \mathrm{O}_{2}$. Cyclic voltammetry in aerobic buffer of films of cyt $\mathrm{P} 450$ or $\mathrm{Mb}$, or indeed almost any iron heme protein, shows the characteristic increase in reduction current and disappearance of the $\mathrm{PFe}^{\mathrm{II}}$ oxidation peak (Fig. 4) due to its electrochemical catalytic reaction with oxygen. ${ }^{30,33}$

LbL films containing $\mathrm{Mb}$ and cyt P450cam on Au foil electrodes were used for catalysis of styrene epoxidation, using electrolysis in solutions containing oxygen and styrene. GC-MS was used to monitor the sole enzyme reaction product styrene oxide. The enzymes mediated the electrochemical reduction of oxygen to hydrogen peroxide, which activates the heme proteins to catalyze olefin oxidation (Scheme 2).

Biocatalysis with LbL films was compared with surfactant films containing the same model enzymes for catalytic oxidation of styrene derivatives to epoxides. ${ }^{35}$ No products were found using bare electrodes with enzymes dissolved in solution. Enzyme-polyion films on Au electrodes coated with mercaptopropane sulfonate gave the best catalytic activities for these oxidations. Improved performance of enzyme-polyion films is related to efficient, reversible heme $\mathrm{Fe}^{\mathrm{III}}-\mathrm{Fe}^{\mathrm{II}}$ electron transfer, and better mechanical stability than the surfactant films under hydrodynamic conditions. Furthermore, dependence of product stereochemistry on availability of oxygen in the reaction medium for oxidation of cis- $\beta$ methylstyrene suggested two pathways for olefin oxidation, uncovered for the first time for cyt P450s. ${ }^{35}$ The stereoselective pathway depends on an active, high valent iron-oxygen intermediate as in the natural enzyme system, e.g. ${ }^{\circ} \mathrm{PFe}^{\mathrm{IV}}=\mathrm{O}$ (see Scheme 2). A second, nonstereoselective pathway is likely to involve olefin oxidation by a peroxyl radical on an amino-acid residue at the protein's surface.

LbL films of the human cyt P450 1A2 were grown with PSS on higher surface area (i.e., than Au-foil) carbon cloth electrodes and evaluated for electrochemical- and $\mathrm{H}_{2} \mathrm{O}_{2}$-driven enzyme-catalyzed oxidation of styrene to styrene oxide. ${ }^{38}$ At an applied voltage of $-0.6 \mathrm{~V}$ vs. SCE in an electrochemical cell, epoxidation of styrene was again mediated by catalytic reduction of dioxygen to $\mathrm{H}_{2} \mathrm{O}_{2}$ (Scheme 2). This approach was compared to purely chemical activation by adding $10 \mathrm{mM} \mathrm{H}_{2} \mathrm{O}_{2}$. For cyt $\mathrm{P} 4501 \mathrm{~A} 2$, slightly larger turnover rates were found for electrolytic and $\mathrm{H}_{2} \mathrm{O}_{2}$-driven reactions compared to conventional enzymic reactions using cyt P450s, reductases, and NADPH. Cyt $\mathrm{P}^{2} 50_{\text {cam }}$ gave comparable turnover rates in film electrolysis and enzyme solution reactions. ${ }^{38}$ Results showed that cyt P450 1A2 catalyzes styrene epoxidation faster than cyt $\mathrm{P} 450_{\mathrm{cam}}$, and suggested the usefulness of this thin-film method for relative kinetic studies of cyt P450s.

Finally, biocatalytic properties of LbL films containing $\mathrm{Mb}$ and cyt $\mathrm{P} 450_{\text {cam }}$ were optimized with respect to film thickness, polyion type and $\mathrm{pH} .{ }^{33}$ Again, electrochemical and peroxide- 
driven epoxidation of styrene was the test reaction. Synthetic organic polyions such as PSS, as opposed to $\mathrm{SiO}_{2}$ nanoparticles or DNA, supported the best catalytic and electrochemical performance. The charge transport mechanism is likely to involve electron hopping facilitated by extensive interlayer mixing within the films. Very thin films (ca. 12-25 nm) gave the largest turnover rates for catalytic epoxidation, and thicker films became limited by in-film reactant transport. ${ }^{33}$ Classical bell-shaped activity-pH profiles and turnover rates similar to those in solution again supported LbL films as excellent tools for relative kinetic studies of enzymes. Major advantages include greatly enhanced enzyme stability and the tiny amount of enzyme required.

In related work on a mediated enzyme, Calvo and co-workers reported fundamental studies of LbL films of glucose oxidase (GOx) assembled with ferrocene- or osmium polymer mediators on electrodes. Studies of the order of layer deposition identified conditions for efficient catalysis. GOx retained high enzyme activity while the redox polyelectrolyte acted as a "molecular wire" enabling good electrical communication between the enzyme and the underlying electrodes. ${ }^{39}$

\section{Enhancing stability of enzyme LbL films}

Layered polyion-enzyme films have storage stability up to several months at $4{ }^{\circ} \mathrm{C}$ as long as the enzyme is stable. Under hydrodynamic conditions typically used for biocatalysis, we found that the mechanical stability of LbL enzyme films on PG electrodes is much better than lipid films or cast or spin cast polyion-protein films. Such observations suggested that LbL films would be more useful than many alternatives for sensor, bioreactor and biofuel cell applications.

While conventional LbL films are quite stable on rough PG electrodes, films grown on less adhesive surfaces such as quartz or glass often have unacceptable stability. However, crosslinking between proteins in Mb-PSS films promoted by 1-[3-(dimethylamino)propyl]-3ethylcarbodiimide (EDC) greatly improved adhesion of the films to fused silica slides for spectroscopic studies. ${ }^{40}$ Fig. 5(a) shows Soret band VIS spectra characteristic of the PFe ${ }^{\mathrm{III}}$ heme group of intact $\mathrm{Mb}$ at $411 \mathrm{~nm}$. The spectra indicate that crosslinked films on fused silica showed minimal degradation over 60 days, while non-cross-linked LbL films degraded much more rapidly. However, very good stability of the same uncrosslinked films on rough PG suggests that stability is controlled here by film-solid adhesion.

When crosslinked Mb-PSS films were immersed in $0.1 \mathrm{M} \mathrm{HCl}$, a blue shift in the $\mathrm{Mb}$ Soret band was observed (Fig. 5(b)) characteristic of structural changes in the region of the heme. Return of the acid-treated films to $\mathrm{pH} 7.5$ buffer regenerated the band at $411 \mathrm{~nm}$ at a somewhat smaller absorbance. This shows that the acid-induced structural change was partly reversible. ${ }^{40}$ In contrast, $\mathrm{Mb}$ dissolved in $0.1 \mathrm{M} \mathrm{HCl}$ is irreversible denatured and loses the iron heme.

UV circular dichroism (CD) spectra are excellent monitors of protein secondary structure. ${ }^{41}$ Native $\mathrm{Mb}$ in solution has double minima at 210 and $222 \mathrm{~nm}$ representing predominant (76\%) a-helical regions. ${ }^{42}$ Similar minima in crosslinked Mb film CD spectra were found at 208 and $222 \mathrm{~nm}$. Taken together with the characteristic Mb Soret bands, these spectra suggest near native, stable structure of the protein in the films in buffers between $\mathrm{pH} 2$ and 11. In contrast, $\mathrm{Mb}$ retains native structure in solution only between $\mathrm{pH} 5$ to 9 . Remarkably, little change in the $\mathrm{CD}$ spectrum was found after $\mathrm{Mb}$ films were immersed in $0.1 \mathrm{M} \mathrm{HCl}$ solution for up to $5 \mathrm{~min}$ (Fig. 5(c)), suggesting that the reversible acid-induced structural changes were mainly in the vicinity of the heme region (Fig. 5(b)). 
At $\mathrm{pH} 1, \mathrm{Mb}$ in solution is fully unfolded, but Fig. 5(c) shows that it retained nearly all of its a-helical content in the crosslinked LbL films. Both the polyion film environment and crosslinking seem to play roles in stabilizing protein secondary structure and function at low $\mathrm{pH}$. Crosslinked Mb-polyion films on pyrolytic graphite electrodes were used in strongly acidic solutions for the electrochemical catalytic reduction of trichloroacetic acid, hydrogen peroxide, and oxygen. ${ }^{40}$ The catalytic reduction of trichloroacetic acid by the films was faster in $0.1 \mathrm{M} \mathrm{HCl}$ than in the medium $\mathrm{pH}$ range.

Microemulsions are dynamic, stable, clear, nanostructured mixtures of oil, water, surfactant and often a co-surfactant such as a medium-chain-length alcohol. They are useful for biocatalysis because they can dissolve organic reactants in their oil nanophases while keeping the enzymes in LbL films in a largely aqueous environment. ${ }^{43-45}$ Additional stabilization was required for LbL films to be usable in microemulsions. Excellent stability and catalytic efficiency in buffers and microemulsions at room temperature was obtained for LbL films on electrodes by linking $\mathrm{Mb}$ to poly(L-lysine) (PLL) covalently bound to graphite electrodes. ${ }^{43}$

Crosslinked films consisting of two bilayers of poly(L-lysine) (PLL) and enzymes covalently linked to surfaces provided remarkable thermostability, enabling biocatalysis at $90{ }^{\circ} \mathrm{C} .{ }^{37}$

Films were made one layer at a time, but EDC-promoted crosslinking was used at every step of film construction (Fig. 6(a)). Soret spectra, CD and voltammetry showed that PLL films containing soybean peroxidase (SBP), horseradish peroxidase (HRP) or Mb had intact enzyme structures and were stable for up to $9 \mathrm{~h}$ at $90^{\circ} \mathrm{C}$, while the same enzymes in solution denatured completely in $<20 \mathrm{~min}$. LbL films and crosslinking procedures like those discussed here are likely to fix the enzyme in its native folded state with a much higher energy barrier to unfolding compared to the same enzyme dissolved in solution.

Rotating disk voltammetry data for the biocatalytic reduction of $t$ - $\mathrm{BuOOH}$ with peroxidasePLL films gave a good fit to the electrochemical Michaelis-Menten equation, and provided rate $\left(k_{\mathrm{cat}}\right)$ and substrate binding constants $\left(K_{\mathrm{m}}\right)$. Relative ratios $k_{\mathrm{cat}} / K_{\mathrm{m}}$, a measure of catalytic efficiency, showed that HRP-PLL films were three-fold more efficient than SBPPLL at $25^{\circ} \mathrm{C}$, but SBP-PLL was slightly more active at $90^{\circ} \mathrm{C}$. SBP-PLL films had eightfold larger $k_{\mathrm{cat}} / K_{\mathrm{m}}$ at $90^{\circ} \mathrm{C}$ compared to $25^{\circ} \mathrm{C}$.

Crosslinked HRP- and SBP-PLL films were also constructed on carboxylated $500 \mathrm{~nm}$ diameter silica beads to make biocatalytic particles or biocolloids. ${ }^{37}$ Oxidation of classic peroxidase substrate $o$-methoxyphenol (10) to $3,3^{\prime}$-dimethoxy-4, $4^{\prime}$-biphenoquinone (12, Scheme 3$)^{46}$ by peroxidase-PLL-coated silica microbeads was studied. Reactions were initiated by injection of $t$-BuOOH into a dispersion of enzyme-PLL beads and substrate. Product absorbance at $480 \mathrm{~nm}$ reached a steady state at all temperatures within $\sim 8 \mathrm{~min}$, at which point all $t$ - $\mathrm{BuOOH}$ was consumed. Absorbance at steady state under these conditions is a measure of the yield of product 12, which increased with temperature (Fig. 7). ${ }^{37}$ Compared to $25^{\circ} \mathrm{C}$, yields of product 12 increased 2-fold at $90^{\circ} \mathrm{C}$ and 1.5 -fold at $60{ }^{\circ} \mathrm{C}$. While yields for HRP and SBP films were roughly the same at $25^{\circ} \mathrm{C}$, yields were significantly larger for SBP films at 60 and $90{ }^{\circ} \mathrm{C}$, in line with the better inherent thermostability of SBP. Both biocolloids gave better yields at $90{ }^{\circ} \mathrm{C}$ than $25^{\circ} \mathrm{C}$, suggesting increasing catalytic efficiency and selectivity of the multi-step oxidation of $\mathbf{1 0}$ to $\mathbf{1 1}$ to 12 (Scheme 3) because of the increase in thermal energy. These biocolloids were reusable at 90 ${ }^{\circ} \mathrm{C}$ with only minor loss of activity. 


\section{Biosensors for genotoxicity screening}

\section{Genotoxicity}

Chemicals that humans ingest or are exposed to must be assessed for toxicity. Extensive experience in toxicity screening and prediction has been gained in the pharmaceutical industry. As drug costs are directly tied to candidate failures ${ }^{47}$ it is important to predict drug toxicity at very early stages of development. ${ }^{48}$ While many good methods have been developed for assessing aspects of drug toxicity, we perceived an unfilled niche for simple, inexpensive, high throughput screening sensors and arrays usable at very early stages of drug development. ${ }^{49}$

Reactions of molecules or their enzyme-generated metabolites with DNA nucleobases can produce covalently linked nucleobase adducts which may initiate cancer. ${ }^{22-24}$ These nucleobase adducts most often occur on guanines and adenines in DNA, and they are good biomarkers for cancer risk. ${ }^{50,51}$ This mechanism for DNA damage is called genotoxicity. "Bioactivation" is the term used for generation of reactive metabolites by cyt P450s and other metabolic enzymes. Examples of substrates giving DNA-reactive metabolites include styrene, benzo[a]pyrene, tamoxifen, nitrosamines and napthylamines. ${ }^{52-56}$

\section{Electrochemical sensors for genotoxicity screening}

The use of LbL films to develop biosensors was recently reviewed. ${ }^{57}$ In this section, we focus on our quest to develop biosensor arrays for genotoxicity screening utilizing metabolic enzymes and DNA in LbL films (Fig. 6(b)). ${ }^{49,58,59}$ These films are $20-40 \mathrm{~nm}$ thick to minimize mass transport limitations. The enzyme reaction is the first step of sensor operation. Cyt P450 enzymes in the films are activated by small concentrations ( $\triangleleft \mathrm{mM}$ ) of hydrogen peroxide in the reverse of the well-known hydrogen peroxide shunt (see Schemes 1 and 2). Several reports detailed changes in product distributions when activating cyt P450s using peroxides..$^{20,60,61}$ However, in cases examined in our laboratory to date, hydrogen peroxide activation gives the same metabolites as natural cyt P450 activation by NADPH and cyt $\mathrm{P} 450$ reductase, and is appropriate and convenient for use in these sensors. The LbL film "nanoreactor" on the sensor synthesizes reactive metabolites in the vicinity of large concentrations of DNA in the film. The rate of DNA damage from metabolite-nucleobase adduct formation is a measure of relative genotoxicity, and can be detected by voltammetric, ${ }^{8}$ electrochemiluminescent, ${ }^{62}$ or LC-MS/MS methods. ${ }^{63,64}$

Our first step in biosensor development was to evaluate methodologies to detect DNA damage. LbL films of DNA and polycations were used with no enzymes, and incubated with known DNA damaging agents including epoxides and methylating agents. ${ }^{8,65}$ The most successful electrochemical detection employed square wave voltammetry (SWV) for DNA oxidation using soluble catalyst $\mathrm{Ru}(\mathrm{bpy})_{3}{ }^{2+}$ or a catalytic Ru-polyvinylpyridine polymer $\left[\mathrm{Ru}(\mathrm{bpy}){ }_{2}{ }^{2+} \mathrm{Cl}-\mathrm{PVP}\right.$ or $\left.\mathrm{ClRu}-\mathrm{PVP}\right)$ within the film to provide "reagentless" sensors. ${ }^{65}$ The signal results mainly from catalytic electrochemical oxidation of the guanines ${ }^{66}$ in DNA (Scheme 4). Detection relies on the fact that partly unfolded and ss-DNA have more accessible guanines $(\mathrm{G})$ than ds-DNA. As DNA is damaged, it partly unfolds, making the guanines in the damaged ds-DNA more accessible to the Ru catalysts and providing larger signals.

Direct measurement of altered nucleobases by LC-MS from DNA-PDDA films that had been reacted with damage agents and hydrolyzed confirmed that the sensors actually detect DNA damage. ${ }^{64,67}$ For example, sensor ratios (peak after incubation/initial peak) showed excellent correlations with the rate of formation of $N-7$-methylguanine found by LC-MS during incubation with methyl methane sulfonate (MMS) (Fig. 8) and epoxides. These correlations demonstrate that the slopes of sensor response $v s$. incubation time measure 
relative rates of formation of damaged nucleobases, and can be used as indicators of relative genotoxicity. Sensor and LC-MS results also correlated well with animal genotoxicity estimated by $\mathrm{TD}_{\mathrm{Lo}}$ (lowest dose producing carcinogenicity) in mice and rats. ${ }^{67,68}$

Prototype sensors capable of genotoxicity screening of chemicals and their metabolites combined enzyme bioactivation with detection of DNA damage, mimicking events in the human liver. LbL films were made from cyt P450s and DNA on PG electrodes (Fig. 6(b)). ${ }^{8}$ Enzymes were activated by small amounts of $\mathrm{H}_{2} \mathrm{O}_{2}$ to produce metabolites that react with ds-DNA as they diffuse out of the film. DNA damage detection employed catalytic SWV oxidation with dissolved $\mathrm{Ru}(\mathrm{bpy}){ }_{3}{ }^{2+}$. In later versions of these electrochemical sensors, DNA damage was detected by using an inner catalytic ClRu-PVP polymer layer. ${ }^{65}$ Again, results confirmed that sensor response was indicative of DNA damage.

Differences in levels and distributions of cyt P450s may predispose certain individuals to higher risks of drug and chemical toxicity. ${ }^{69,70}$ For this reason, its important to know which enzymes make toxic metabolites from a particular substrate or drug candidate. Thus, the next step in our work was to design arrays featuring a number of cyt P450s to facilitate such analyses. We first demonstrated this approach in an eight-electrode array with cyt $\mathrm{P} 450_{\text {cam }}$, human cyt P450 $1 \mathrm{~A} 2$ and $\mathrm{Mb}^{71}$ Benzo[a]pyrene $(\mathrm{B}[\mathrm{a}] \mathrm{P})$ was chosen as a test substrate because of its relatively complex but well understood metabolism resulting in several DNAreactive metabolites from cyt $\mathrm{P} 450$ catalyzed oxidations. ${ }^{72-74}$ DNA damage in the arrays was detected as above by increases in SWV peak ratios using soluble Ru(bpy $)_{3}{ }^{2+}$ as catalyst. Fig. 9 shows data from such an array expressed as sensor peak ratio vs. enzyme incubation time. ${ }^{71}$ Initial slopes of these plots were divided by the amount of each enzyme obtained by QCM to give relative turnover rates $\left\{(\mathrm{nmol} \text { enzyme })^{-1} \mathrm{~cm}^{-2} \mathrm{~min}^{-1}\right\}$ of 3.0 for cyt $\mathrm{P} 450_{\text {cam }}$, 3.5 for cyt P450 1A2 and 0.9 for Mb. Cyt P450 cam and cyt P450 1A2 showed three-fold higher activity for bioactivation of $\mathrm{B}[\mathrm{a}] \mathrm{P}$ for DNA damage than the model enzyme $\mathrm{Mb}$, as expected.

\section{Electrochemiluminescent (ECL) sensors for genotoxicity screening}

In ECL, an electrochemically driven redox reaction provides an ion or molecule in a photoexcited state from which light emission can be measured. For example, when $\mathrm{Ru}(\mathrm{bpy}) 3_{3}{ }^{2+}$ is oxidized to $\mathrm{Ru}(\mathrm{bpy}) 3_{3}{ }^{3+}$, ECL can be generated by using a sacrificial reductant, often tripropylamine or oxalate. This produces photoexcited $\left[\mathrm{Ru}(\mathrm{bpy}) 3^{2+}\right]^{*}$ by a pathway involving reaction of a radical form of the reductant with electrochemically generated $\mathrm{Ru}(\mathrm{bpy}) 3_{3}{ }^{3+} \cdot{ }^{75-77}$ Alternatively, $\mathrm{Ru}(\mathrm{bpy})_{3}{ }^{+}$is formed by reduction of $\mathrm{Ru}(\mathrm{bpy})_{3}{ }^{2+}$ by the radical, followed by combination of $\mathrm{Ru}^{\mathrm{I}}$ and $\mathrm{Ru} \mathrm{III}^{\mathrm{II}}$ complexes to give $\left[\mathrm{Ru}(\mathrm{bpy}){ }_{3}{ }^{2+}\right]^{*},{ }^{78}$ which decays to ground state by emitting $610 \mathrm{~nm}$ light. ECL with $\mathrm{Ru}(\mathrm{bpy}) 3^{2+}$-labeled DNA using a sacrificial reductant provides a very sensitive method to detect oligonucleotide hybridization. ${ }^{79-81}$

In collaboration with Robert Forster at Dublin City University, we found that the polymer $\left[\mathrm{Ru}(\mathrm{bpy})_{2}(\mathrm{PVP})_{10}\right]^{2+}(\mathrm{Ru}-\mathrm{PVP}, \mathrm{PVP}=$ poly (vinylpyridine $)$ ) shown in Scheme 5 can be electrochemically activated in LbL films to react with DNA and generate ECL directly. ${ }^{62}$ That is, DNA itself can act as the sacrificial reductant. We used SWV to oxidize Ru ${ }^{\mathrm{II}}$ sites in the metallopolymer to $\mathrm{Ru}^{\mathrm{III}}$, which oxidizes DNA. ECL was measured simultaneously with SWV (Fig. 10) by positioning an optical fiber under the Ru-PVP-DNA electrode outside the cell (Scheme 5), and directing the light via a monochromator to a photomultiplier tube. ECL was generated only when guanine bases were present on DNA strands in the films, suggesting that guanine radicals initially formed by catalytic oxidation of guanines in DNA by $\mathrm{Ru}^{\mathrm{III}}$ (eqn (6)) react with the metallopolymer to produce electronically exited $\mathrm{Ru}^{\mathrm{II} *}$ sites in the film (eqn (7), Scheme 6). Alternatively, $\mathrm{Ru}^{\mathrm{I}}$-PVP can be formed from reaction of 
$\mathrm{Ru}^{\mathrm{II}}-\mathrm{PVP}$ with $\mathrm{G}^{\bullet}$, and can then react with $\mathrm{Ru}^{\mathrm{III}}-\mathrm{PVP}$ to produce the excited $\mathrm{Ru}^{\mathrm{II} *}$ state to give ECL.

ECL and SWV peaks increased during incubation of Ru-PVP-DNA films with known DNA damage agent styrene oxide. ${ }^{62}$ Control incubations in buffer containing unreactive toluene resulted in no significant changes in ECL or SWV. We recently showed that LbL films incorporating DNA, enzymes and Ru-PVP can be used to make simultaneous ECL/SWV toxicity screening sensors. ${ }^{82}$

The ECL approach is well suited to instrumentally convenient, high throughput toxicity screening arrays. Individually addressable array electronics are not required. We recently reported a prototype ECL array with a single $2.5 \mathrm{~cm}^{2}$ pyrolytic graphite (PG) block electrode in a cell housed in a dark box with a CCD camera for detection (Scheme 7). ${ }^{83} \mathrm{Up}$ to 50 small individual spots, each an LbL film containing DNA, enzyme and Ru-PVP, were manually micropipetted onto the PG block. Upon application of $1.25 \mathrm{~V} v s$. SCE, the electrochemically oxidized Ru-PVP generates light from each spot by oxidizing guanines in the DNA (Scheme 6). As in all catalytic DNA detection schemes, larger signals are obtained from damaged DNA because of better accessibility of the guanines to the catalyst as the dsDNA unravels. ${ }^{8}$ Rates of DNA damage from metabolites produced by individual cyt P450s were estimated simultaneously from the increase in ECL intensity with reaction time. ${ }^{83}$

ECL arrays can be configured to measure the time course of reactions catalyzed by a single enzyme, or multiple enzyme reactions for a single substrate can be followed simultaneously. Data obtained with the array can be re-organized and presented in any way desired by computer software.

Fig. 11(a) shows an ECL array with 49 RuPVP-DNA-enzyme spots designed to study the time dependence of DNA damage for the bioactivation of benzo[a]pyrene by human cyt $\mathrm{P} 450$ 1B1 enzyme. The array spots were exposed to $0.5 \mathrm{mM} \mathrm{H}_{2} \mathrm{O}_{2}$ and $100 \mu \mathrm{M} \mathrm{B}[\mathrm{a}] \mathrm{P}$ for various times marked on the array image. ECL intensity increased with enzyme reaction time as shown by increases in light intensity. Control spots exposed to $\mathrm{B}[\mathrm{a}] \mathrm{P}$ or $\mathrm{H}_{2} \mathrm{O}_{2}$ alone showed little change in ECL, showing that $\mathrm{H}_{2} \mathrm{O}_{2}$ activates the enzymes but does not damage DNA. Fig. $11 \mathrm{~b}$ is an ECL ratio plot from these experiments.

Again using B[a]P as substrate, Fig. 12 illustrates results of reactions with five enzymes in similar arrays. Relative rates of DNA damage were estimated simultaneously in $\sim 1 \mathrm{~min}$ of enzyme reaction time and $20 \mathrm{~s}$ of array development time. The linear signal increases indicative of DNA damage rate are illustrated by the graph on the right of Fig. 12.

Bioactivation producing DNA damage taken as the initial slopes of these graphs was in the order cyt $\mathrm{P} 4501 \mathrm{~B} 1>$ cyt $\mathrm{P} 4501 \mathrm{~A} 2>$ cyt $\mathrm{P}_{50} 0_{\text {cam }}>$ cyt $\mathrm{P} 4502 \mathrm{E} 1>\mathrm{Mb}$, the same as the order of relative metabolic activity of these enzymes towards $\mathrm{B}[a] \mathrm{P} .{ }^{83}$ Thus, the slope of the initial linear increase estimates the relative activity of different enzymes to produce reactive metabolites ${ }^{83}$ We have also compared ECL arrays to voltammetric sensors for genotoxicity studies of $N$-nitrosopyrrolidine. ${ }^{84}$ This work showed that human cyt P450 2E1 bioactivated $\mathrm{N}$-nitrosopyrrolidine for DNA damage, but $\mathrm{Mb}$ did not.

\section{DNA release from LBL films}

Non-analytical biomedical applications of LbL DNA films have also been reported. A very interesting biomedical application features LbL films designed to release DNA upon incubation under physiological conditions by Lynn and co-workers. ${ }^{85-88}$ Specifically, films of a poly ( $\beta$-amino ester) (cationic) and DNA encoded for enhanced green fluorescent protein (EGFP) were shown to degrade during incubation in PBS buffer at $37^{\circ} \mathrm{C}$ over a period of $20 \mathrm{~h}$ to 4 days depending on the number of layers. Films were assembled on 
silicon substrates as well as stainless steel intravascular stents. Degradation occurs via hydrolysis of a poly( $\beta$-amino ester) cation used in film construction. The EGFP-encoded DNA released was taken up when exposed to COS-7 cells which expressed green fluorescent protein over a period of $20-48 \mathrm{~h}$. The hydrolyzed poly ( $\beta$-amino ester) was shown to aid in the uptake of DNA into COS-7 cells. ${ }^{87}$ Atomic force microscopy (AFM), scanning electron microscopy (SEM), ultraviolet-visible spectrometry (UV-Vis), and fluorescent microscopy (FMS) were used to verify film assembly and deconstruction, DNA release, and expression of green fluorescent protein, respectively. ${ }^{86-88}$ One application was the coating of stents with therapeutic genes that could be delivered to the necessary biological site for gene therapy treatment. ${ }^{88}$

Shen and co-workers also developed a DNA LbL film using poly (L-lysine) (PLL) that was capable of releasing DNA. ${ }^{89,90}$ They found that the ionic strength adjusted via concentration of sodium chloride during layering and deconstruction was crucial to the amount of DNA incorporated into the film and hence, released during degradation. ${ }^{89}$ As ionic strength was increased up to $0.5 \mathrm{M} \mathrm{NaCl}$ during film construction, the amount of DNA in the film increased then drastically decreased at $1 \mathrm{M} \mathrm{NaCl} .{ }^{89}$ Decomposition of the DNA-PLL films also increased at high salt concentrations ${ }^{89}$ Thus, controlling the ionic strength provided control over the amount of DNA in the film and its rate of release. Ren and co-workers also employed a-chymotrypsin to metabolize PLL thereby facilitating the release of DNA and degradation of the film. ${ }^{90}$ They observed near linear loss of DNA over a period of $35 \mathrm{~h}$ when exposed to a-chymotrypsin by UV-Vis, AFM and FMS. ${ }^{90}$ This protease digestion system may be a good pathway for gene delivery in vivo. DNA LbL films designed by Lynn and co-workers ${ }^{85-88}$ and Shen and co-workers ${ }^{89,90}$ show promise for use in site-directed gene delivery in hydrolytic biological environments.

\section{Summary and outlook for the future}

We have summarized recent biochemical applications of versatile LbL films in biocatalysis and early toxicity screening, taking examples mainly from our own research. The ability to combine multiple polyions and biomolecules in the same film to provide multiple, improved or new functionalities has allowed the realization of these applications. For example, enzyme-PLL films stabilized by crosslinking can be used for biocatalysis at unprecedented high temperatures or in acidic or basic solutions on electrodes or on microbeads. Such films have bright prospects for chiral synthesis and biofuel cells. Furthermore, the excellent performance and retention of secondary structure and bioactivity of enzymes in the LbL films facilitates detailed mechanistic studies of biocatalysis using only tiny amounts of enzyme.

Biosensors employing DNA-enzyme LbL films show great promise in predicting genotoxicity of drugs and environmental chemicals, and should be important future tools in chemical product development studies. These devices combine biocatalysis, DNA reactions, and several DNA damage detection schemes. For example, catalytic voltammetry and ECL can be used as the basis for high throughput arrays based on LbL "spots", with ECL being the more convenient methodology. DNA-enzyme films on high area surfaces or microbeads (as used for the enzymes alone) can be used to make nucleobase adducts via enzyme bioactivation that can be detected by LC-MS. This analysis provides sensor validation by specifically measuring rates of adduct formation that correlate with sensor response vS. incubation time. We are currently developing LbL microbead technology with LC-MS detection that is also complimentary to the sensor arrays since it provides detailed DNA adduct chemical structures and formation rates. In short, the inexpensive array technologies provide rapid non-specific evidence for genotoxicity, while the more complex, more 
expensive LC-MS methods provide an improved approach to identifying metabolitenucleobase adducts and measure their formation rates directly.

Genotoxicity biosensor arrays will eventually be able to simultaneously and rapidly provide relative genotoxicity data for any collections of relevant metabolic enzymes. Preliminary results from our laboratory have also shown that rat liver or genetically enriched cyt P450 microsomes can be used in any of the genotoxicity sensor formats discussed above. Such devices may have great advantages for general screening in very early stages of drug development and discovery.

\section{Acknowledgments}

The authors' work described herein was supported by US PHS grant No. ES03154 from the National Institute of Environmental Health Sciences (NIEHS), NIH, USA and by Grant No. CTS-0335345 from the National Science Foundation (NSF).

\section{Biographies}

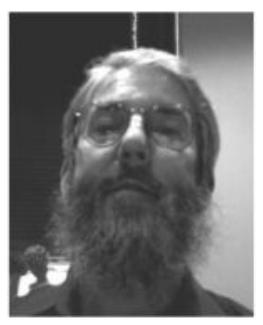

James F. Rusling

James F. Rusling was born in 1946 in Philadelphia. He was awarded a BSc in Chemistry from Drexel University and a PhD in Chemistry from Clarkson University, the latter working with Professor Petr Zuman. In 1979, he joined the faculty of the University of Connecticut, where he currently Professor of Chemistry and Professor of Pharmacology (Health Center). His current research interests are in nanoscience-based sensor arrays for toxicity prediction and early cancer detection, biocatalysis, and nanoparticle-based drug delivery. He has authored over 250 refereed research papers, a book on chemical and biochemical data analysis, and has edited two research monographs. He is also an accomplished musician who plays traditional Irish and American music on accordion, guitar, banjo and harmonica at local venues and in several bands.

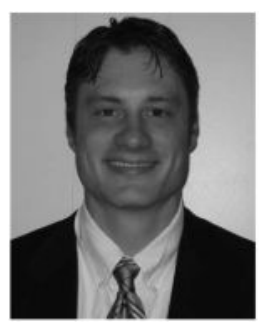

\section{Eli G. Hvastkovs}

Eli G. Hvastkovs was born in 1977 in Casper, Wyoming. He was awarded both a BA and $\mathrm{PhD}$ in Chemistry from the University of Wyoming, the latter working with Professor Daniel Buttry. He joined the Rusling group in 2004 as a Postdoctoral Fellow at the University of Connecticut in the Departments of Chemistry and Cell Biology (Health 
Center). His current research interests are exploring molecular biological angles in the development of in vitro sensor arrays for toxicity/cancer prediction, and developing unique sensor based methods for the detection of drug or pollutant induced genetic abnormalities. $\mathrm{He}$ is also an avid sports junkie and enjoys spending time with his family.

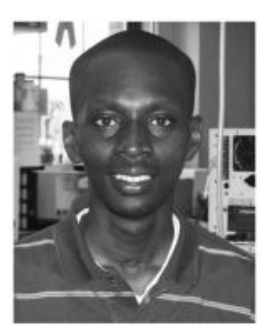

\section{Dominic O. Hull}

Dominic O. Hull earned a BS in chemistry from the State University of New York at Buffalo. He received his PhD in bio-inorganic chemistry from the University of North Carolina at Chapel Hill under the supervision of Prof. H. Holden Thorp in 2005. His studies focused on metal-mediated electrocatalytic oxidation kinetics for DNA, carbon nanotubes and polypeptides. Currently, he is a postdoctoral fellow at the University of Connecticut under the supervision of Prof. James F. Rusling. His current work is focused on inhibition of cyt P450-generated genotoxic metabolites in electrochemical DNA biosensors using antioxidants.

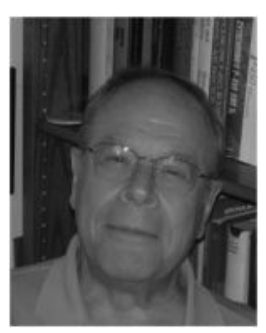

\section{John B. Schenkman}

Dr John Schenkman is Professor of Pharmacology and Cell Biology at the University of Connecticut Health Center in Farmington, CT. He received his BA in Chemistry from Brooklyn College and PhD in Biochemistry from State University of NY, Upstate Medical Center. He did postdoctoral studies on cytochrome P450 at the Johnson Foundation of the U. of Pennsylvania, Osaka University Institute of Protein Research and University of Tübingen Institut fur Toxikologie before becoming Assistant Professor of Pharmacology at Yale U. School of Medicine. Dr Schenkman left Yale to become Professor and Chairman of Pharmacology of the University of Connecticut. He stepped down as Chairman in 1987, is currently Professor Emeritus, and is still active in research involving the cytochrome P450 system.

\section{References}

1. Decher G, Hong JD. Ber. Bunsen-Ges. Phys. Chem. 1991; 95:1430.

2. Decher G, Hong JD, Schmitt J. Thin Solid Films. 1992; 210:831.

3. Lvov Y, Decher G, Möhwald H. Langmuir. 1993; 9:481.

4. Lvov, Y. Protein Architecture: Interfacing Molecular Assemblies and Immobilization Biotechnology. Lvov, Y.; Möhwald, H., editors. Marcel Dekker; New York: 2000. p. 125-167. 
5. Lvov, Y. Handbook Of Surfaces And Interfaces Of Materials, Vol. 3 Nanostructured Materials, Micelles and Colloids. Nalwa, RW., editor. Academic Press; San Diego, CA: 2001. p. 170-189.

6. Rusling, JF. Protein Architecture: Interfacing Molecular Assemblies and Immobilization Biotechnology. Lvov, Y.; Möhwald, H., editors. Marcel Dekker; New York: 2000. p. 337-354.

7. Ariga, K.; Kunitake, T. Protein Architecture: Interfacing Molecular Assemblies and Immobilization Biotechnology. Lvov, Y.; Möhwald, H., editors. Marcel Dekker; New York: 2000. p. 169-192.

8. Zhou L, Yang J, Estavillo C, Stuart JD, Schenkman JB, Rusling JF. J. Am. Chem. Soc. 2003; 125:1431-1436. [PubMed: 12553846]

9. Decher G. Science. 1997; 227:1232-1237.

10. Ariga K, Hill JP, Ji Q. Phys. Chem. Chem. Phys. 2007; 9:2319-2340. [PubMed: 17492095]

11. Zhang X, Chen H, Zhang H. Chem. Commun. 2007:1395-1405.

12. Lvov Y, Ichinose I, Kunitake T. J. Am. Chem. Soc. 1995; 117:6117-6123.

13. Rusling, JF.; Zhang, Z. Biomolecular Films. Rusling, JF., editor. Marcel Dekker; New York: 2003. p. 1-64.

14. Yokota T, Itoh K, Fujishima A. J. Electroanal. Chem. 1987; 216:289-292.

15. Salamon Z, Tollin G. Bioelectrochem. Bioenerg. 1991; 25:447-454.

16. Salamon Z, Tollin G. Bioelectrochem. Bioenerg. 1991; 26:321-334.

17. Armstrong FA, Heering HA, Hirst J. Chem. Soc. Rev. 1997; 26:169-179.

18. Tarlov MJ, Bowden EF. J. Am. Chem. Soc. 1991; 113:1847-1849.

19. Schenkman, JB.; Greim, H., editors. Cytochrome P450. Springer-Verlag; Berlin: 1993.

20. Ortiz de Montellano, PR., editor. Cytochrome P450. 3rd edn. Kluwer/Plenum; New York: 2005.

21. Singer, B.; Grunberger, D. Molecular Biology of Mutagens and Carcinogens. Plenum Press; New York: 1983.

22. Jacoby, WB., editor. Enzymatic Basis of Detoxification. Vol. I and II. Academic; New York: 1980.

23. Friedberg EC. Nature. 2003; 421:436-440. [PubMed: 12540918]

24. Scharer OD. Angew. Chem., Int. Ed. 2003; 42:2946-2974.

25. Lippard, SJ.; Berg, JM. Principles of Bioorganic Chemistry. University Science Books; Mill Valley, CA: 1994.

26. Guengerich FP. Chem. Res. Toxicol. 2001; 14:611-650. [PubMed: 11409933]

27. Guengerich FP, Bell LC, Okazaki O. Biochemie. 1995; 77:573-580.

28. Ortiz de Montellano PR, De Voss JJ. Nat. Prod. Rep. 2002; 19:477-493. [PubMed: 12195813]

29. Zhang Z, Nassar A-EF, Lu Z, Schenkman JB, Rusling JF. J. Chem. Soc., Faraday Trans. 1997; 93:1769-1774.

30. Lvov YM, Lu Z, Schenkman JB, Zu X, Rusling JF. J. Am. Chem. Soc. 1998; 120:4073-4080.

31. Buttry DA, Ward MD. Chem. Rev. 1992; 92:1355-1379.

32. Ma H, Hu N, Rusling JF. Langmuir. 2000; 16:4969-4975.

33. Munge B, Estavillo C, Schenkman JB, Rusling JF. ChemBioChem. 2003; 4:82-89. [PubMed: 12512080]

34. Schenkman JB, Jansson I, Lvov Y, Rusling JF, Boussaad S, Tao NJ. Arch. Biochem. Biophys. 2001; 385:78-87. [PubMed: 11361029]

35. Zu X, Lu Z, Zhang Z, Schenkman JB, Rusling JF. Langmuir. 1999; 15:7372-7377.

36. Adam W, Lazarus M, Saha-Möller CR, Weichold O, Hoch U, Häring D, Schreier P. Adv. Biochem. Eng./Biotechnol. 1999; 63:73-108.

37. Guto PM, Kumar CV, Rusling JF. J. Phys. Chem. B. 2007 in press.

38. Estavillo C, Lu Z, Jansson I, Schenkman JB, Rusling JF. Biophys. Chem. 2003; 104:291-296. [PubMed: 12834847]

39. (a) Hodak J, Etchenique R, Calvo EJ, Singhal K, Bartlett PN. Langmuir. 1997; 13:2708-2716.(b) Calvo EJ, Etchenique R, Pietrasanta L, Wolosiuk A. Anal. Chem. 2001; 73:1161-1168. [PubMed: 11305646] (c) Calvo EJ, Forzani ES, Otero M. J. Electroanal. Chem. 2002; 538-539:231-241.(d) Calvo EJ, Wolosiuk A. ChemPhysChem. 2004; 5:235-239. [PubMed: 15038285] Calvo EJ, 
Wolosiuk A. ChemPhysChem. 2005; 6:43-47. [PubMed: 15688642] (e) Flexer V, Forzani ES, Calvo EJ, Luduena SJ, Pietrasanta LI. Anal. Chem. 2006; 78:399-407. [PubMed: 16408920]

40. Panchagnula V, Kumar CV, Rusling JF. J. Am. Chem. Soc. 2002; 124:12515-12525. [PubMed: 12381195]

41. Holzwarth G, Doty P. J. Am. Chem. Soc. 1965; 87:218-228. [PubMed: 14228459]

42. Rusling, JF.; Kumosinski, TF. Nonlinear Computer Modeling of Chemical and Biochemical Data. Academic Press; New York: 1996. p. 117-134.

43. Vaze A, Parizo M, Rusling JF. Langmuir. 2004; 20:10943-10948. [PubMed: 15568844]

44. Vaze A, Rusling JF. Langmuir. 2006; 22:10788-10795. [PubMed: 17129061]

45. Guto PM, Rusling JF. J. Phys. Chem. B. 2005; 109:24457-24464. [PubMed: 16375448]

46. Doerge DR, Divi RL, Churchwell MI. Anal. Biochem. 1997; 250:11-17.

47. Caldwell GW, Yan L. Curr. Opin. Drug Discovery Dev. 2006; 9:47-50.

48. Nasser AEF, Kamel AM, Clarimont C. Drug Discovery Today. 2004; 9:1055-1064. [PubMed: 15582794]

49. Rusling JF, Hvastkovs EG, Schenkman JB. Curr. Opin. Drug Discovery Dev. 2007; 10:67-73.

50. Phillips DH, Farmer PB, Beland FA, Nath RG, Poirier MC, Reddy MV, Turtletaub KW. Environ. Mol. Mutagen. 2000; 35:222-233. [PubMed: 10737957]

51. Warren AJ, Shields PG. Proc. Soc. Exp. Biol. Med. 1997; 216:172-180. [PubMed: 9349686]

52. Bond JA. CRC Crit. Rev. Toxicol. 1989; 19:227-249.

53. Pauwels W, Vodiceka P, Servi M, Plna K, Veulemans H, Hemminki K. Carcinogenisis. 1996; 17:2673-2680.

54. Umemoto A, Komaki K, Monden Y, Suwa M, Kanno Y, Kitagawa M, Suzuki M, Lin C-X, Ueyama Y, Momen MA, Ravindernath A, Shibutani S. Chem. Res. Toxicol. 2001; 14:1006-1013. [PubMed: 11511174]

55. Wang M, McIntee EJ, Shi Y, Cheng G, Upadhyaya P, Villalta PW, Hecht SS. Chem. Res. Toxicol. 2001; 14:1435-1445. [PubMed: 11599936]

56. Cavalieri EL, Rogan EG, Devaneshan PD, Cremonesi P, Cerny RL, Gross ML, Bodell WJ. Biochemistry. 1990; 29:4820-4827. [PubMed: 2364062]

57. Zhao W, Xu J, Chen H. Electroanalysis. 2006; 18:1737-1748.

58. Rusling, JF. Electrochemistry of Nucleic Acids and Proteins. Palecek, E.; Scheller, F.; Wang, J., editors. Elsevier; Amsterdam: 2005. p. 433-450.

59. Rusling JF. Biosens. Bioelectron. 2004; 20:1022-1028. [PubMed: 15530799]

60. Bichara N, Ching MS, Blake CL, Ghabrial H, Smallwood RA. Drug Metab. Dispos. 1996; 24:112118. [PubMed: 8825198]

61. Kupfer R, Liu SY, Allentoff AJ, Thompson JA. Biochemistry. 2001; 40:11490-11501. [PubMed: 11560497]

62. Dennany L, Forster RJ, Rusling JF. J. Am. Chem. Soc. 2003; 125:5213-5218. [PubMed: 12708874]

63. Tarun M, Bajrami B, Rusling JF. Anal. Chem. 2006; 78:624-627. [PubMed: 16408950]

64. Tarun M, Rusling JF. Crit. Rev. Eukaryotic Gene Express. 2005; 15:295-315.

65. Wang B, Rusling JF. Anal. Chem. 2003; 75:4229-4235. [PubMed: 14632140]

66. Johnston DH, Glasgow KC, Thorp HH. J. Am. Chem. Soc. 1995; 117:8933-8938.

67. Tarun M, Rusling JF. Anal. Chem. 2005; 77:2056-2062. [PubMed: 15801738]

68. Yang J, Wang B, Rusling JF. Mol. Biosyst. 2005; 1:251-259. [PubMed: 16880989]

69. Gonzalez FJ. Trends Pharmacol. Sci. 1992; 13:346-352. [PubMed: 1529480]

70. Guengerich FP. Trends Pharmacol. Sci. 1989; 10:107-109. [PubMed: 2688217]

71. Wang B, Jansson I, Schenkman JB, Rusling JF. Anal. Chem. 2005; 77:1361-1367. [PubMed: 15732919]

72. Neilson, AH., editor. PAHs and Related Compounds. Springer; Berlin: 1998. 
73. Rogan EG, Devanesan PD, Ramakrishna NVS, Higgenbotham S, Padvavathi NS, Chapman K, Cavalieri EL, Jeong H, Jankowiak R, Small GJ. Chem. Res. Toxicol. 1993; 6:356-363. [PubMed: 7686408]

74. Todorovic R, Ariese F, Devenesan P, Jankowiak R, Small GJ, Rogan EG, Cavalieri EL. Chem. Res. Toxicol. 1997; 10:941-947. [PubMed: 9305574]

75. Ege D, Becker WG, Bard AJ. Anal. Chem. 1984; 56:2413-2417. [PubMed: 6517331]

76. Xu X-H, Yang HC, Mallouk TE, Bard AJ. J. Am. Chem. Soc. 1994; 116:8386-8387.

77. Kenten JH, Casedei J, Link J, Lupold S, Willey J, Powell M, Rees A, Massey RJ. Clin. Chem. 1991; 37:1626. [PubMed: 1654234]

78. Rubinstein I, Bard AJ. J. Am. Chem. Soc. 1980; 102:6642-6644.

79. Xu X-H, Bard AJ. J. Am. Chem. Soc. 1995; 117:2627-2631.

80. Leland JK, Powell MJ. J. Electrochem. Soc. 1990; 137:3127-3131.

81. Blackburn GF, Shah HP, Kenten JH, Leland J, Kamin RA, Link J, Petermann J, Powell MJ, Shah A, Talley DB, Tyagi SK, Wilkins E, Wu T-G, Massey RJ. Clin. Chem. 1991; 37:1534-1539. [PubMed: 1716534]

82. So M, Hvastkovs EG, Schenkman JB, Rusling JF. Biosens. Bioelectron. submitted.

83. Hvastkovs EG, So M, Krishnan S, Bajrami B, Tarun M, Jansson I, Schenkman JB, Rusling JF. Anal. Chem. 2007; 79:1897-1906. [PubMed: 17261025]

84. Krishnan S, Hvastkovs EG, Bajrami B, Jansson I, Schenkman JB, Rusling JF. Chem. Commun. 2007:1713-1715.

85. Vazquez E, Dewitt DM, Hammond PT, Lynn DM. J. Am. Chem. Soc. 2002; 124:13992-13993. [PubMed: 12440887]

86. Zhang J, Chua LS, Lynn DM. Langmuir. 2004; 20:8015-8021. [PubMed: 15350066]

87. Jewell CM, Zhang J, Fredin NJ, Lynn DM. J. Controlled Release. 2005; 106:214-223.

88. Jewell CM, Zhang J, Fredin N, Wolff MR, Hacker TA, Lynn DM. Biomacromolecules. 2006; 7:2483-2491. [PubMed: 16961308]

89. Ren K, Wang Y, Ji J, Shen J. Colloids Surf., B. 2005; 46:63-69.

90. Ren K, Ji J, Shen J. Biomaterials. 2006; 27:1152-1159. [PubMed: 16102814] 

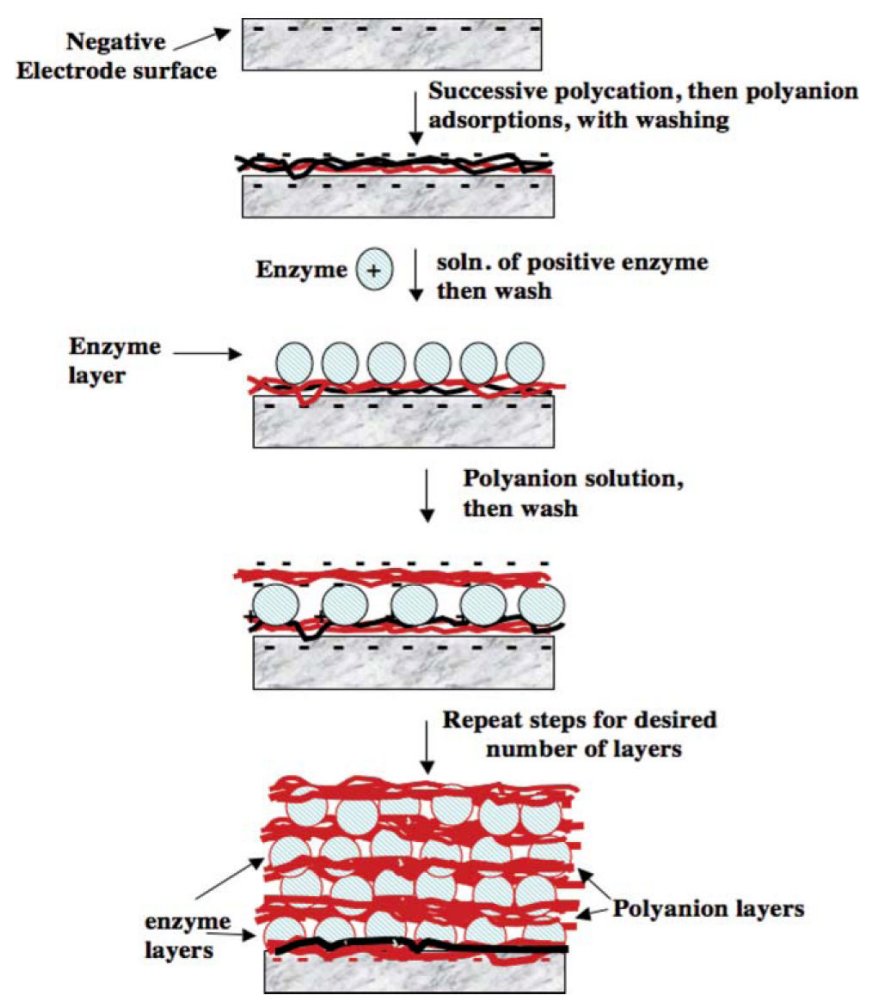

Fig. 1.

LbL methodology illustrated for enzyme films. 

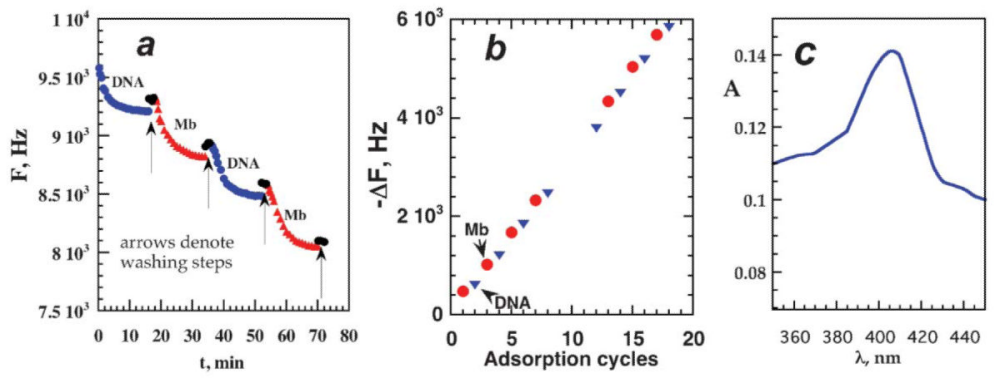

Fig. 2.

QCM monitoring of growth of LbL films of DNA and myoglobin (Mb) on an Au-MPS-Mb underlayer on a Au-quartz resonator: (a) in situ kinetics of several sequential steps of $\mathrm{Mb}-$ DNA assembly, (b) linear growth for dried Mb-DNA multilayers films at pH 5. Steps 8-11 were assembled without interrupting the process for drying, and (c) visible absorbance spectrum of (Mb-PSS $)_{8}$ multilayer film on quartz showing the iron heme Soret band characteristic of structurally intact $\mathrm{Mb}$ at $\sim 410 \mathrm{~nm}$. Adapted with permission from ref. 30 . Copyright 1998, American Chemical Society. 


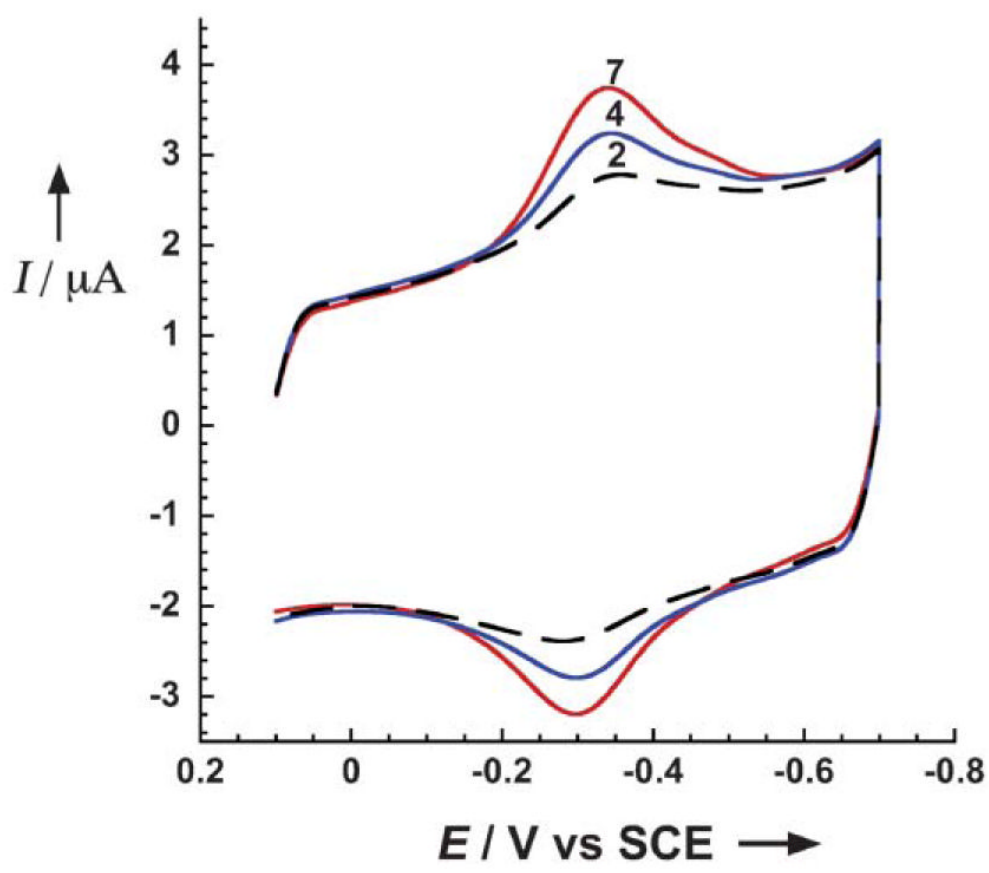

Fig. 3.

Cyclic voltammograms at $0.3 \mathrm{~V} \mathrm{~s}^{-1}$ for $\left(\text { cyt } \mathrm{P} 450_{\text {cam }-\mathrm{PEI}}\right)_{n}$ on rough $\mathrm{PG}$ electrodes in acetate buffer $\mathrm{pH} 5.5+100 \mathrm{mM} \mathrm{NaCl}$ purged with nitrogen. The numbers on the curves denote the number of protein layers. Peaks did not increase beyond seven layers.

Reproduced with permission from ref, 33. Copyright 2003, Wiley-VCH. 


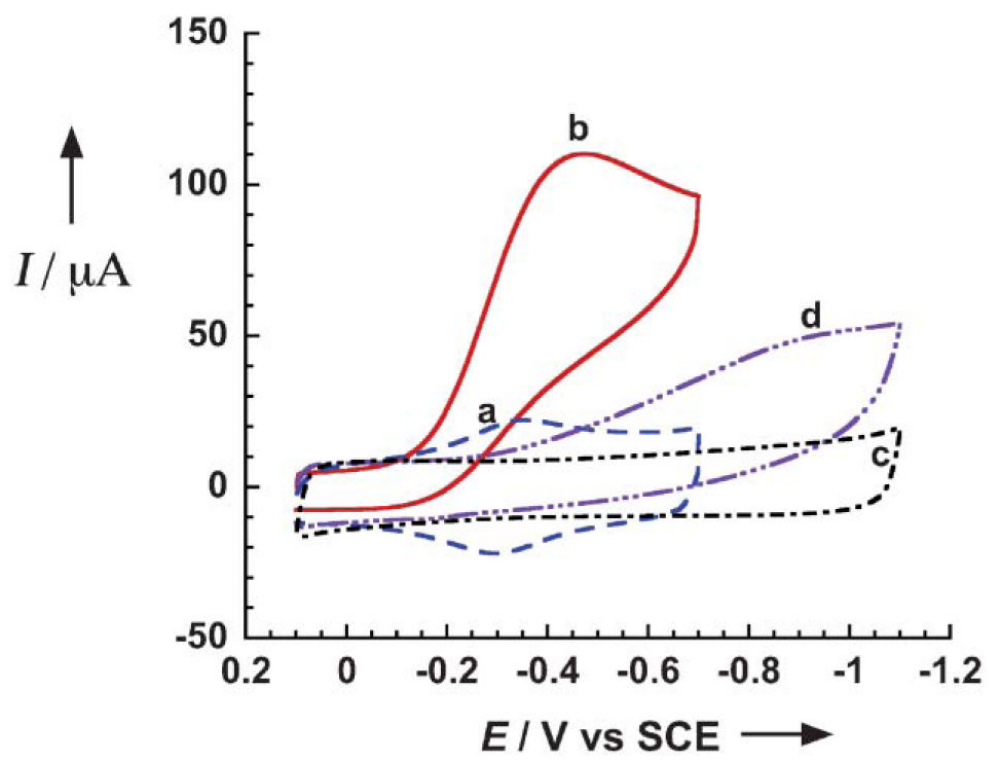

Fig. 4.

Cyclic voltammograms at $0.3 \mathrm{~V} \mathrm{~s}^{-1}$ in $\mathrm{pH} 5.5$ buffer in a sealed cell for: (a) (cyt P450cam$\mathrm{PEI})_{6}$ film with no oxygen present, (b) (cyt $\left.\mathrm{P} 450_{\text {cam }} \mathrm{PEI}\right)_{6}$ after injection of $40 \mathrm{~mL}$ oxygen, (c) PEI monolayer on PG without oxygen present, and (d) PEI monolayer after injection of $40 \mathrm{~mL}$ oxygen. Results confirm the catalytic reduction of oxygen by the enzyme in the film, as in Scheme 1. Reproduced with permission from ref. 33. Copyright 2003, Wiley-VCH. 

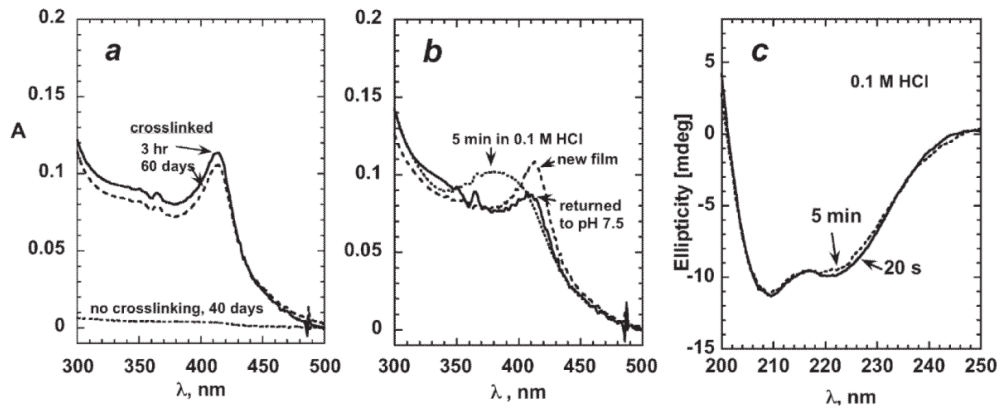

Fig. 5.

Spectra of crosslinked (PDDA-PSS) ${ }_{3}(\mathrm{Mb}-\mathrm{PSS})_{4}$ films on fused silica: (a) UV-Vis spectra showing influence of crosslinking on stability of films stored at $5{ }^{\circ} \mathrm{C}$ in $\mathrm{pH} 7$ buffer. (b) UVVis spectra of a film initially at $\mathrm{pH} 7.5$, immersed for $5 \mathrm{~min}$ in $0.1 \mathrm{M} \mathrm{HCl}$, then returned to pH 7.5 buffer. (c) Circular dichroism spectra after immersion in $0.1 \mathrm{M} \mathrm{HCl}$ solution. The spectrum is virtually identical to that obtained at $\mathrm{pH} 7$ in solution of LbL films. Adapted with permission from ref. 40. Copyright 2002 American Chemical Society. 

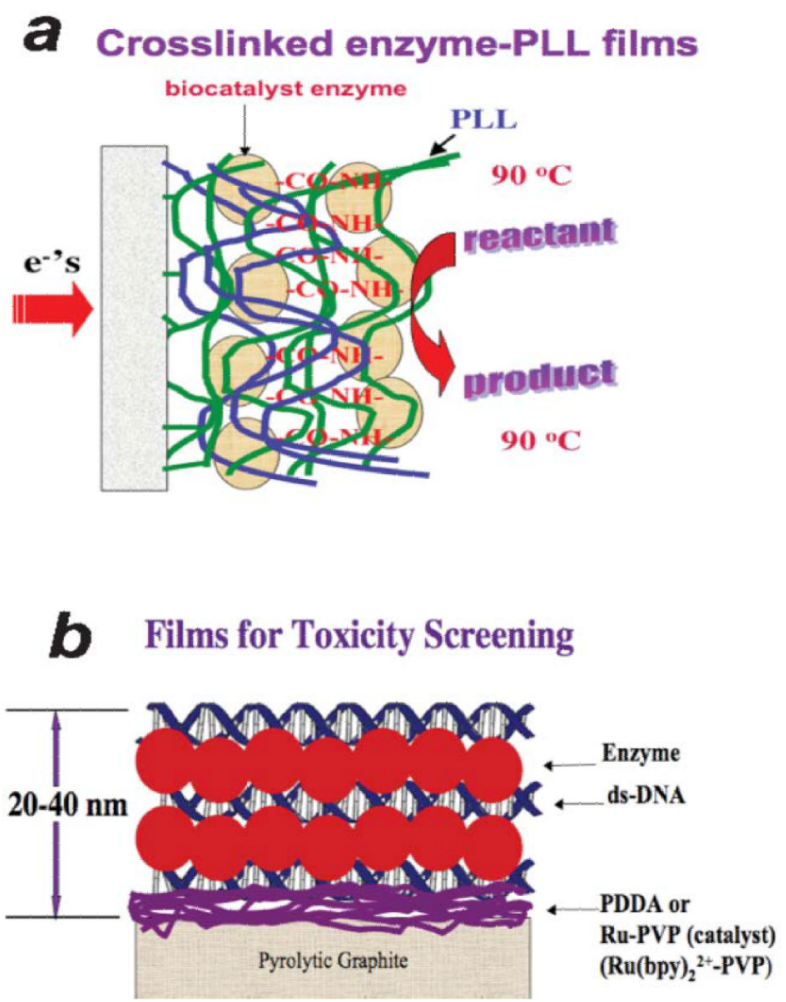

Fig. 6.

Idealized representations of film configurations: (a) cross-linked 2-bilayer enzyme-PLL films on solid surfaces that can be activated for biocatalysis by electrochemistry in the presence of oxygen, or by adding hydrogen peroxide (see Scheme 2). (b) Films used in genotoxicity sensors. The enzyme reaction produces metabolites in close proximity to DNA. Damage to DNA is detected by voltammetry or electrochemiluminescence, or by hydrolysis to eject nucleobase adducts, followed by LC-MS. 

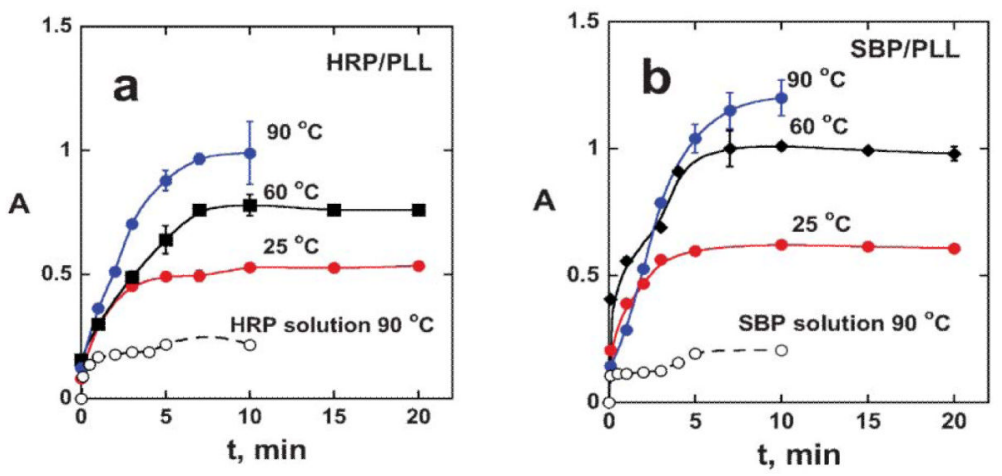

Fig. 7.

Product absorbance at $480 \mathrm{~nm}$ for oxidation of $10 \mathrm{mM}$-methoxyphenol in $\mathrm{pH} 6$ buffer by HRP- and SBP-PLL films on $0.5 \mu \mathrm{m}$ silica beads containing $\sim 8 \mu \mathrm{M}$ enzyme at 25,60 and $90{ }^{\circ} \mathrm{C}$ for (a) HRP-PLL films; (b) SBP-PLL films. Reactions were begun by injecting $5 \mathrm{mM}$ $t$-BuOOH into stirred dispersions. Controls are absorbance for $8 \mu \mathrm{M}$ dissolved enzyme at 90 ${ }^{\circ} \mathrm{C}$. Adapted with permission from ref. 37. Copyright 2007, American Chemical Society. 


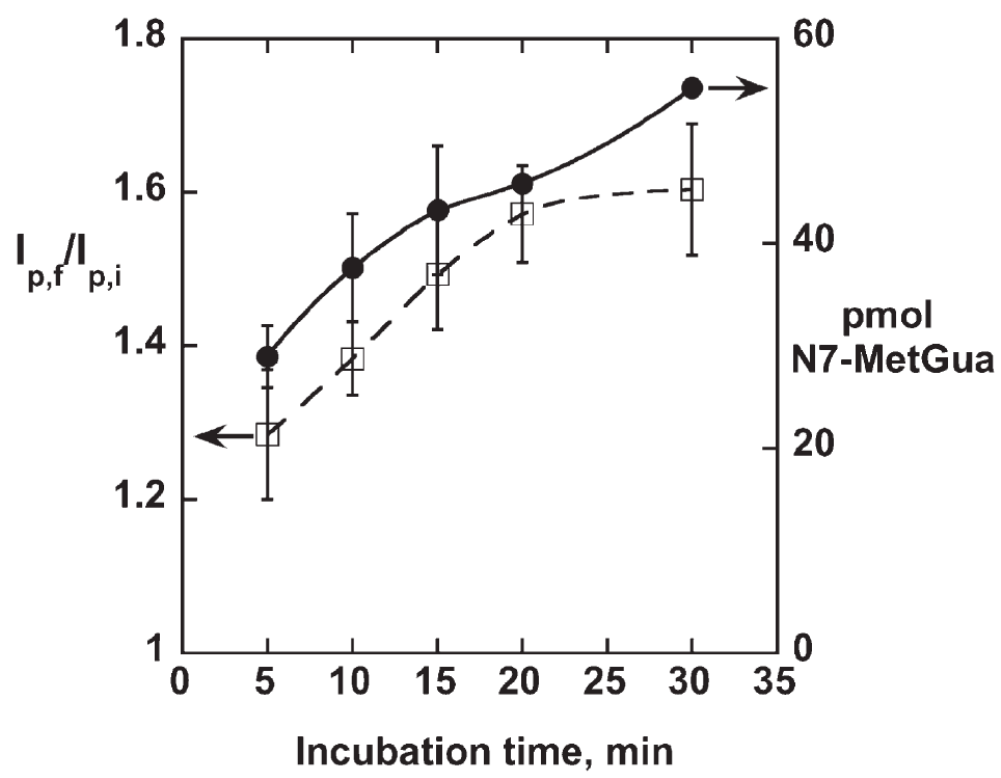

Fig. 8.

Comparisons of electrochemical toxicity sensor and LC-MS data. Peak current ratio $I_{\mathrm{p}, \mathrm{f}} / I_{\mathrm{p}, \mathrm{i}}$ (final/initial) for simple genotoxicity sensors consisting of (PDDA-DNA) $)_{2}$ films on graphite electrode-based sensor $(\square)$, and pmol nucleobase adducts found by LC-MS (O) of hydrolyzed DNA from similar films on carbon cloth. Both assays after incubation of the DNA films with $2 \mathrm{mM}$ MMS. Adapted with permission from ref. 65. Copyright 2005, American Chemical Society. 


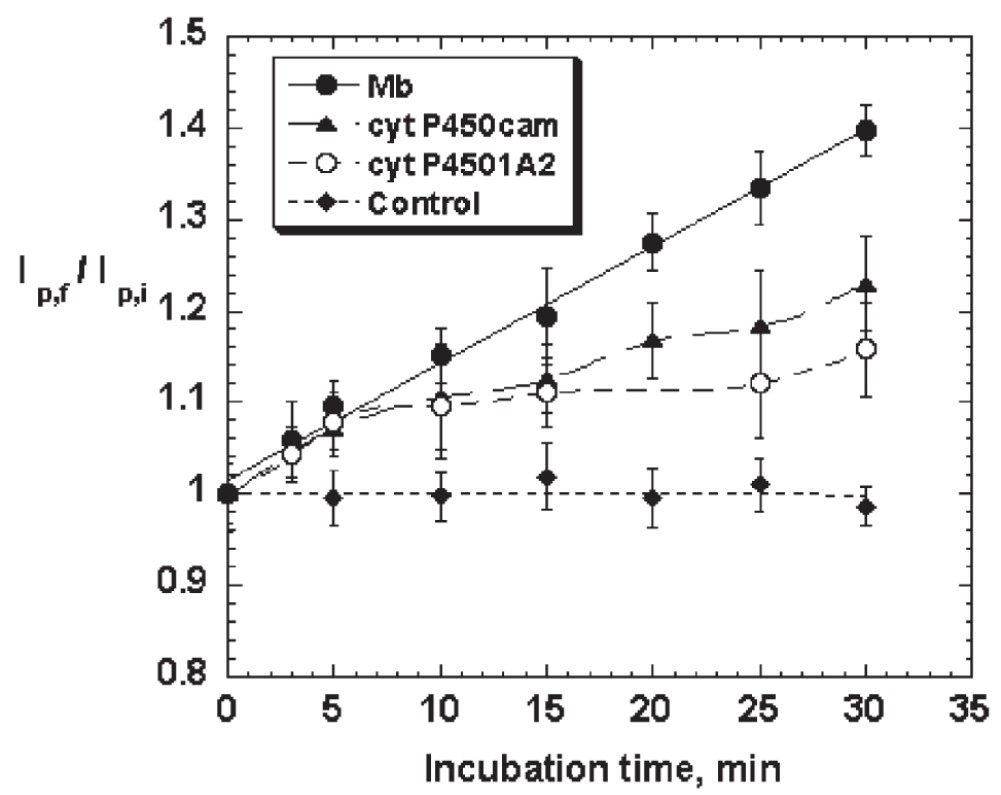

Fig. 9.

Influence of incubation time with $50 \mu \mathrm{M}$ benzo[a]pyrene and $1 \mathrm{mM} \mathrm{H}_{2} \mathrm{O}_{2}$ on the peak current ratios from SWV of PDDA-DNA-(enzyme-DNA) $)_{2}$ films in an eight-electrode array. Control is PDDA-DNA-(Mb-DNA) $)_{2}$ film in $50 \mu \mathrm{M}$ benzo[a]pyrene alone (4 replicates for $\mathrm{Mb}$ films, three each for cyt $\mathrm{P} 450$ films). Amounts of proteins in the films in $\mathrm{nmol} \mathrm{cm}{ }^{-2}$ were 0.26 for Mb, 0.060 for cyt P450cam, and 0.054 for cyt P540 1A2. Adapted with permission from ref. 69. Copyright 2005, American Chemical Society. 


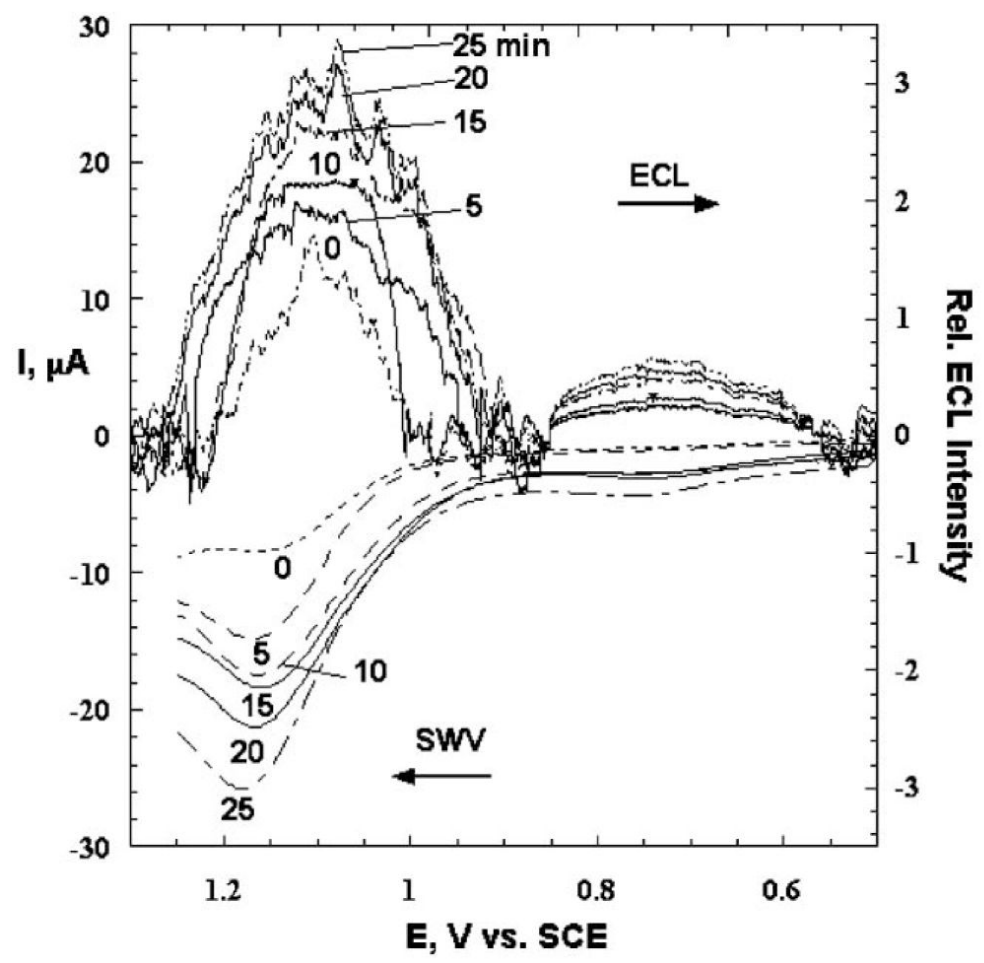

Fig. 10.

Simultaneous SWV and ECL responses for (Ru-PVP-DNA) $)_{2}$ films on PG electrodes in $\mathrm{pH}$ 5.5 buffer $+50 \mathrm{mM} \mathrm{NaCl}$ after incubations at $37{ }^{\circ} \mathrm{C}$ with saturated styrene oxide. Numerical labels are incubation times in min. Adapted with permission from ref. 60. Copyright 2003, American Chemical Society. 

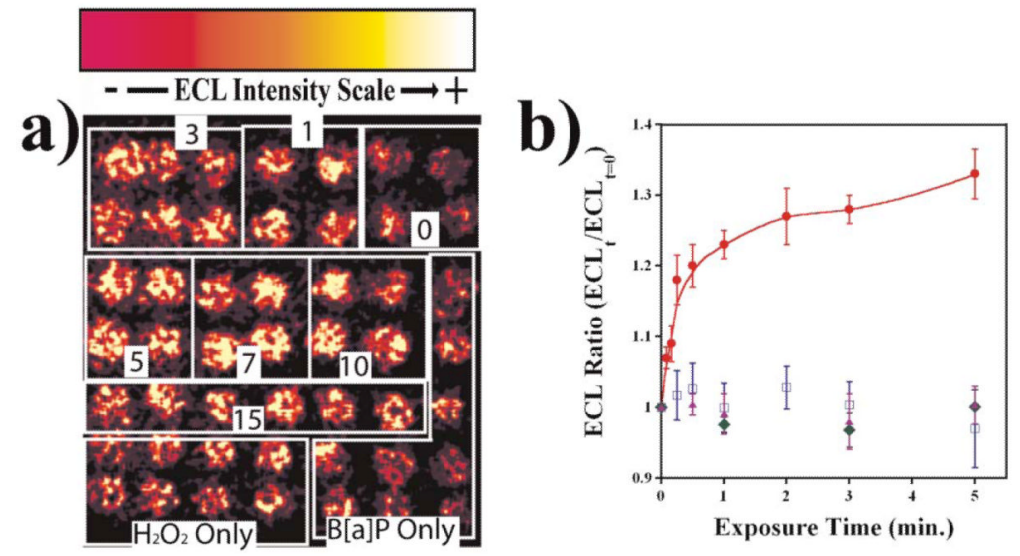

Fig. 11.

(a) CCD image of ECL array with 49 individual RuPVP-DNA-enzyme spots all containing cyt $\mathrm{P} 450$ 1B1. Boxes denote spots that were exposed to $0.5 \mathrm{mM} \mathrm{H}_{2} \mathrm{O}_{2}+100 \mu \mathrm{M} \mathrm{B}[\mathrm{a}] \mathrm{P}$ for the labeled times (min). Controls on bottom were exposed to $\mathrm{B}[\mathrm{a}] \mathrm{P}$ or $\mathrm{H}_{2} \mathrm{O}_{2}$ only for increasing amounts of time from 1-7 min as viewed from right to left (not marked for clarity). (b) ECL ratio plot demonstrating the increase in ECL intensity vs. time of enzyme reaction. Controls show ECL response vs. time exposed to $\mathrm{B}[\mathrm{a}] \mathrm{P}$ only (blue squares), $\mathrm{H}_{2} \mathrm{O}_{2}$ only (green diamonds), and $0.5 \mathrm{mM} \mathrm{H}_{2} \mathrm{O}_{2}+100 \mu \mathrm{M} \mathrm{B}[\mathrm{a}] \mathrm{P}+30 \mu \mathrm{M}$ of inhibitor aNF (purple triangles). Adapted with permission from ref. 83. Copyright 2003, American Chemical Society. 

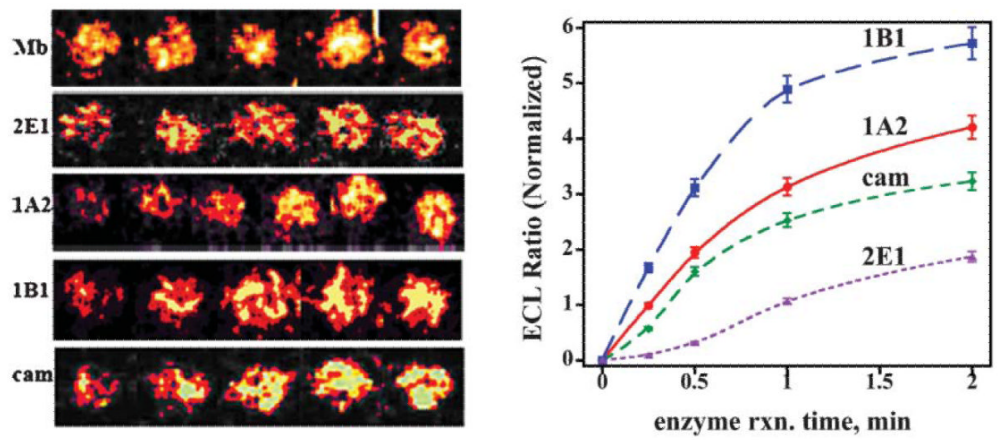

Fig. 12.

ECL array results for enzyme reactions with $100 \mu \mathrm{M}$ benzo[a]pyrene $+0.5 \mathrm{mM} \mathrm{H}_{2} \mathrm{O}_{2}$ (a) reconstructed images for reaction times of $0,1,3,5$ and 7 min for cyt P450 enzymes and myoglobin on the same array. CCD images are recolorized with the brighter spots showing more DNA damage. (b) ECL final/initial ratios normalized for the amount of enzyme in each spot. Adapted with permission from ref. 81. Copyright 2003, American Chemical Society. 


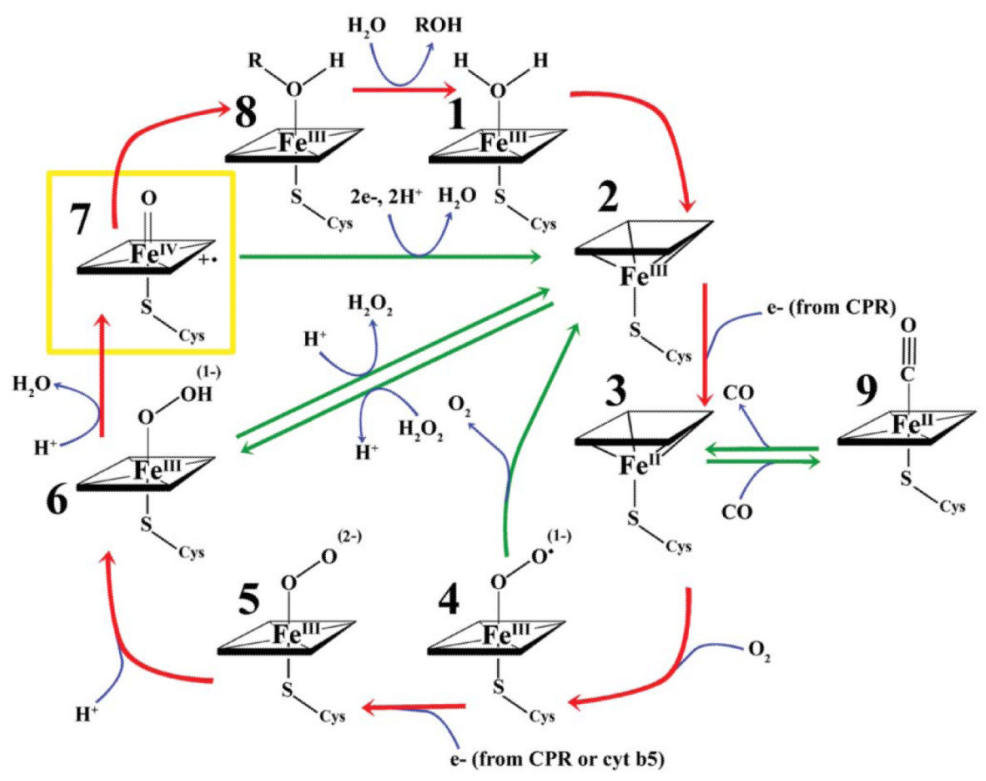

Scheme 1.

The cytochrome P450 catalytic cycle (adapted from various sources ${ }^{20,25-28}$ ). 


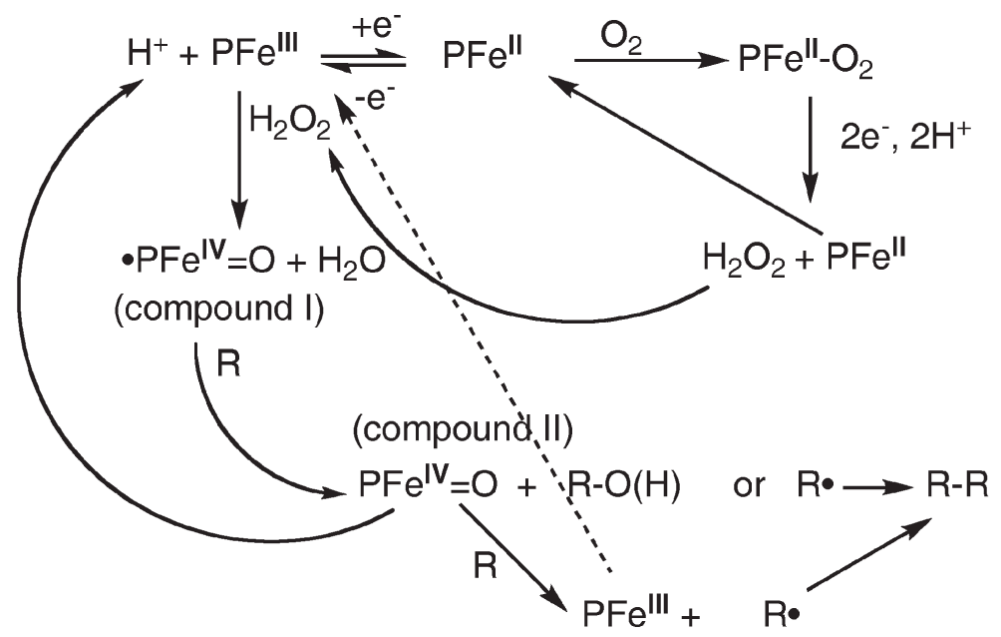

Scheme 2.

General biocatalytic pathways of cyt P450s, Mb and peroxidases in LbL films initiated by electrochemistry or peroxides $(\mathrm{R}=$ substrate $)$. 
<smiles>COc1ccccc1O</smiles>

10

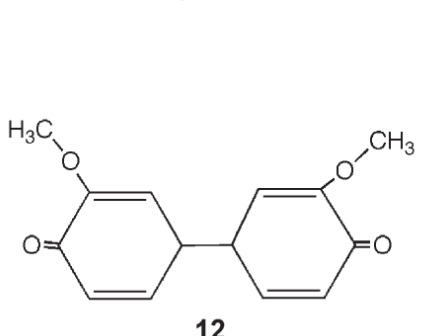

12<smiles>COC1=CCC=CC1=O</smiles><smiles>C1C[13CH]2CC12</smiles>

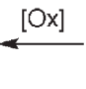
HO<smiles>COc1cc(-c2ccc(O)c(OC)c2)ccc1O</smiles>

Scheme 3.

Pathway for peroxidase catalyzed oxidation of $o$-methoxyl-phenol. 


$$
\begin{aligned}
& \mathrm{ClRu}^{\mathrm{II}}-\mathrm{PVP} \leftrightarrow \mathrm{ClRu}^{\mathrm{III}}-\mathrm{PVP}+\mathrm{e}^{-} \text {(at electrode) } \\
& \mathrm{ClRu}^{\mathrm{III}}-\mathrm{PVP}+\mathrm{G} \rightarrow \mathrm{ClRu} u^{\mathrm{II}}-\mathrm{PVP}+\mathrm{G}^{\cdot}+\mathrm{H}^{+}
\end{aligned}
$$

Scheme 4.

Catalytic electrochemical cycle for DNA damage detection illustrated for ClRu-PVP. 


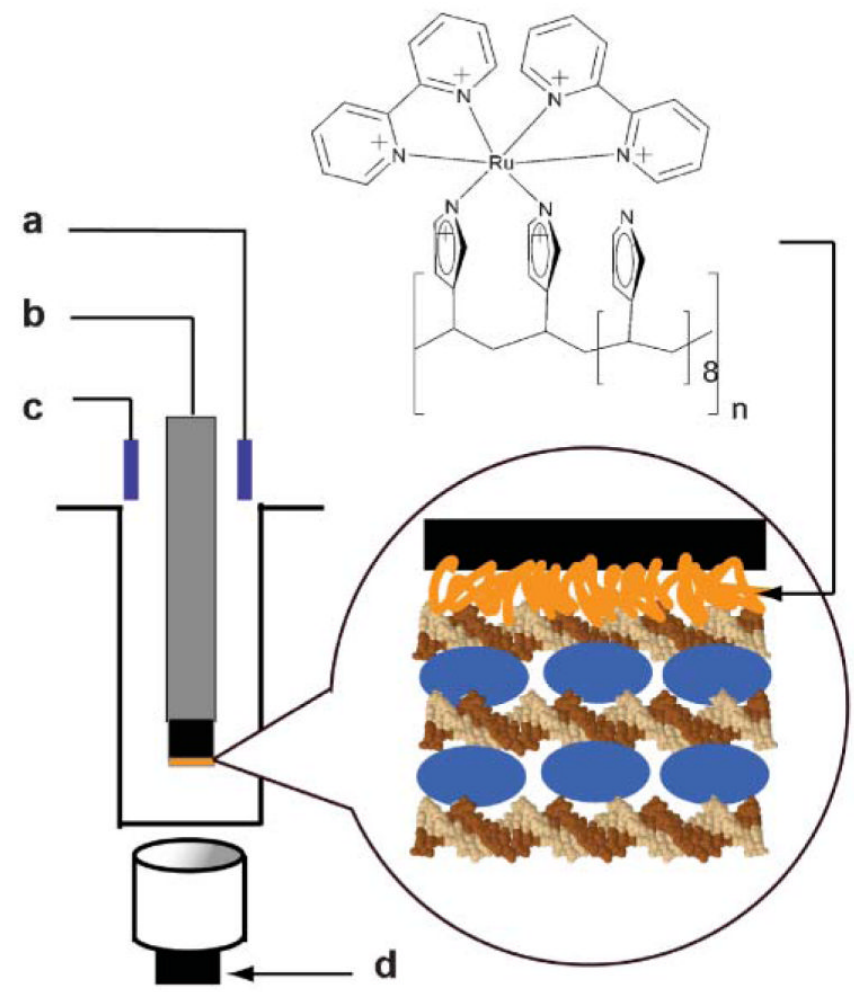

Scheme 5.

Sensor system for simultaneous ECL and voltammetry detection. The SCE reference electrode (a), PG working electrode (b) and Pt counter electrode (c) are located in a glass cell with an extended cylindrical glass base. A fiber optic cable (d) is positioned on the outside of the cell directly under the sensor surface. Ru-PVP, DNA (brown), and enzyme (blue) layers forming the active sensor film are shown to the right. The structure of the (RuPVP) ECL catalyst is shown at the top. For clarity, only one layer of RuPVP is shown on the sensor, although several can be used to enhance $S / \mathrm{N}$. 


$$
\begin{aligned}
& \mathrm{Ru}^{\mathrm{II}}-\mathrm{PVP} \leftrightarrow \mathrm{Ru}^{\mathrm{III}}-\mathrm{PVP}+\mathrm{e}^{-} \text {(at electrode) } \\
& \mathrm{Ru}^{\mathrm{III}}-\mathrm{PVP}+\mathrm{G} \rightarrow \mathrm{Ru}^{\mathrm{II}}-\mathrm{PVP}+\mathrm{G}^{\cdot}+\mathrm{H}^{+} \\
& \mathrm{G}^{\bullet}+\mathrm{Ru}^{\mathrm{III}}-\mathrm{PVP} \rightarrow \mathrm{G}_{20 \mathrm{x}}+\mathrm{Ru}^{\mathrm{II}^{*}}-\mathrm{PVP} \\
& \mathrm{Ru}^{\mathrm{II}}-\mathrm{PVP} \rightarrow \mathrm{Ru}^{\mathrm{II}}-\mathrm{PVP}+h v(610 \mathrm{~nm})
\end{aligned}
$$

Scheme 6. 


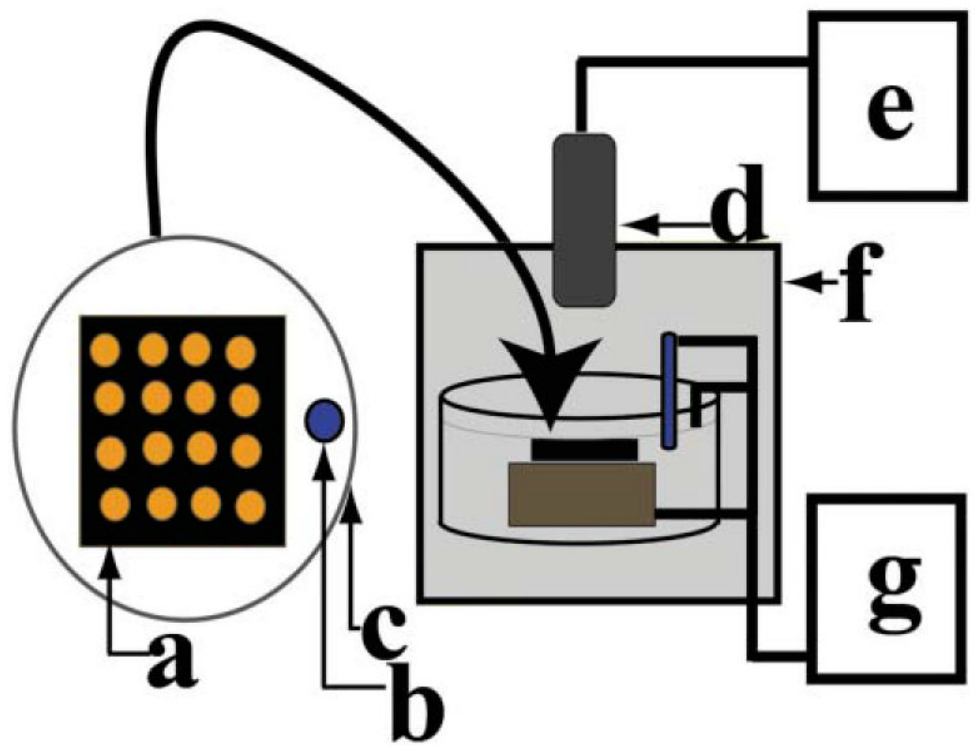

Scheme 7.

ECL arrays from toxicity screening: (a) array; (b) reference electrode; (c) counter electrode; (d) CCD camera; (e) computer; (f) dark box housing; (g) potentiostat for voltage control. 